\title{
Understanding Asthma and Allergies by the Lens of Biodiversity and Epigenetic Changes
}

\author{
Bianca Sampaio Dotto Fiuza ${ }^{1 \dagger}$, Héllen Freitas Fonseca ${ }^{1 \dagger}$, Pedro Milet Meirelles ${ }^{2,3}$, \\ Cintia Rodrigues Marques ${ }^{4}$, Thiago Magalhães da Silva ${ }^{5}$ and \\ Camila Alexandrina Figueiredo ${ }^{1 *}$
}

${ }^{1}$ Instituto de Ciências da Saúde, Universidade Federal da Bahia, Salvador, Brazil, ${ }^{2}$ Instituto de Biologia, Universidade Federal da Bahia, Salvador, Brazil, ${ }^{3}$ Instituto Nacional de Ciência e Tecnologia em Estudos Interdisciplinares e Transdisciplinares em Ecologia e Evolução (IN-TREE), Salvador, Brazil, ${ }^{4}$ Instituto Multidisciplinar em Saúde, Universidade Federal da Bahia, Vitória da Conquista, Brazil, ${ }^{5}$ Departamento de Ciências Biológicas, Universidade Estadual do Sudoeste da Bahia, Jequié, Brazil

Exposure to different organisms (bacteria, mold, virus, protozoan, helminths, among others) can induce epigenetic changes affecting the modulation of immune responses and consequently increasing the susceptibility to inflammatory diseases. Epigenomic regulatory features are highly affected during embryonic development and are responsible for the expression or repression of different genes associated with cell development and targeting/conducting immune responses. The well-known, "window of opportunity" that includes maternal and post-natal environmental exposures, which include maternal infections, microbiota, diet, drugs, and pollutant exposures are of fundamental importance to immune modulation and these events are almost always accompanied by epigenetic changes. Recently, it has been shown that these alterations could be involved in both risk and protection of allergic diseases through mechanisms, such as DNA methylation and histone modifications, which can enhance Th2 responses and maintain memory Th2 cells or decrease Treg cells differentiation. In addition, epigenetic changes may differ according to the microbial agent involved and may even influence different asthma or allergy phenotypes. In this review, we discuss how exposure to different organisms, including bacteria, viruses, and helminths can lead to epigenetic modulations and how this correlates with allergic diseases considering different genetic backgrounds of several ancestral populations.

Keywords: asthma, allergies, holobiont, microbiome, epigenetics

\section{INTRODUCTION}

Asthma and allergy are the most common chronic inflammatory diseases, especially in children (1). The prevalence of asthma is elevated in economically developed countries in Western and Eastern Europe and higher in the United States compared to other countries (2, 3). A progressive increase in the prevalence of asthma in low-income countries has also been observed $(4,5)$, which makes asthma prevalent worldwide. According to the World Health Organization over $80 \%$ of asthma-related deaths occur in low- and low-middle-income countries, and difficulties in accessing treatment and management are also related to that (6). On the other hand, the prevalence of eczema, allergic rhinitis, and food allergies in childhood is distributed differently 
between tropical countries and temperate zones (7-14). Geographic differences in the prevalence of allergies between and within populations may reflect both exposure to common environmental factors and a host genetic background, which can either increase or decrease risk (15). In terms of genetics, large genome-wide association studies (GWAS) initiatives were unable to completely explain such high and still increasing prevalence of allergic disorders as well as their phenotypic heterogeneity (1). Among the top pathways linked to asthma in such initiatives, include those related to epithelial barrier dysfunction and reduction of immune tolerance (16). In addition, studies have found not only shared but also distinct genetic components between asthma subtypes, indicating that heterogeneity is related to individual genotype $(17,18)$ but still do not completely explain everything.

Thus, the knowledge about the interactions between the genetic pool and the environment is increasing with several lines of evidence explaining those trends (19-21). In this context, some hypotheses explain the links between environmental changes that occurred in recent decades with the prevalence of allergies across the globe, such as urbanization, housing condition, diet, and fewer exposures to organisms such as bacteria, virus and helminths $(21,22)$. In fact, there is a link between the higher incidence of allergic diseases and reduced infections/exposure to organisms in Western countries and across the globe and this has been studied for several years now and appears to reflect the economy and sanitation in each territory. Additionally, the degree of industrialization and consequent changes in the habits and lifestyle of the population imply that limited exposure to several environmental factors for reducing biodiversity may contribute to an increased risk of developing or exacerbating asthma and allergies (23). David Strachan observed in 1989 that infections transmitted in early childhood, through contact between older siblings, could restrict the development of allergies $(22,24)$. Urbanization and improvements in hygiene, better housing conditions, and reduced chances of cross-infection in younger members of the family are the basis for what we know as the "hygiene hypothesis" (24). The initial mechanistic explanation of the hygiene hypothesis emphasized the role of Th1 cells in regulating Th2 responses. Later, the role of regulatory $\mathrm{T}$ cells was emphasized in the regulation of both Th1 and Th2-induced inflammatory responses through mechanisms that include the production of regulatory cytokines (25). The mechanistic pathways of the hygiene hypothesis were described extensively in the literature, other theories amplified the initial concept such as the "old friends" hypothesis (26) and, afterwards, the biodiversity hypothesis, proposed by The Karelia Allergy Study from 1998 (27). Both theories attempt to explain the impact of modifications in human living conditions and habits on the prevalence of immune-mediated diseases $(28,29)$.

\footnotetext{
Abbreviations: AAI, allergic airway inflammation; BCG, Bacillus CalmetteGuérin; CpG, cytosine-phosphate-guanine; ERK, Extracellular signal-regulated kinases; ES, excretory/secretory antigens; EWAS, epigenome-wide association studies; GWAS, genome-wide association studies; HAT, histone acetyltransferase; HAV, Hepatitis A virus; HDAC, histone deacetylase; ICS, inhaled corticosteroids; MAPK, mitogen-activated protein kinase; miRNAs, MicroRNA; SOCS, suppressor of cytokine signaling; STH, soil-transmitted helminths; VNN1, Vanin-1.
}

Studies show that early exposure to antibiotics during childhood increases the risk of developing allergic diseases (30) and also regular anthelmintic use (31). Numerous epidemiologic studies reinforce that the increase in allergic diseases, eczema, and food allergies is inversely related to parasitic infections (32-36). Soil biodiversity and climatic characteristics of a country are also determinants in the types of environmental exposures and consequent development of infectious diseases and allergic sensitization. The climate and biodiversity of the tropics (fauna and flora) favor intestinal helminth infections and the dissemination of human infectious diseases transmitted by vectors like insects (37-42). According to (6), Soil-transmitted helminth infections are distributed in tropical and subtropical areas, with the highest incidence in sub-Saharan Africa, the Americas, China, and East Asia.

The tropics are also marked by sharp economic and social inequalities that reflect health and sanitary conditions and an increased risk of spreading fecal-oral transmission diseases (toxoplasmosis, giardiasis, hepatitis A, worms). In addition, the relationship between helminths and allergies is complex and is influenced by the parasite burden, chronicity, first infection or reinfection, coinfections, and parasite species present in the environment (33). In contrast, allergic sensitization to house dust mite species such as Dermatophagoides pteronyssinus, D. farina, and Blomia tropicalis is prevalent in the tropics, markedly in individuals living in better sanitary conditions and urban areas (43-45).

The importance of environmental exposures does not underestimate the fundamental participation of the family history of atopy and/or asthma and genetic background. Thus, we still have an enormous challenge to explain the occurrence of allergies and asthma. Increasing attention has been given to epigenetic modifications, i.e., modifications in DNA without sequence changes, triggered by individual exposure to environmental factors, for instance, by products of combustion, drugs, diet, and infections. Epigenetic mechanisms, such as DNA methylation and histone modifications, can modulate gene expression upon exposure to a specific environmental agent (46). Such biochemical alterations can alter different targets within the body, leading to the risk or protection of several conditions. In this review, we present the concept of holobiont and discuss how exposure to different organisms, including bacteria, viruses, and helminths, can lead to epigenetic modulations and how this modulation correlates with allergic diseases, taking into account different genetic backgrounds of several ancestral populations.

\section{THE CONTEXT OF MICROBIAL EXPOSURE, THE CONCEPT OF HOLOBIONT, AND THE MECHANISMS INVOLVED IN IMMUNE MODULATION}

\section{Holobiont Concept}

Microbes are the most ancient, abundant and arguably the greatest successful form of life on Earth, contributing to the evolution and function of all more complex multicellular organisms (47). Since the early days of life, microbes interacted 
and established intrinsic symbiotic relationships which could evolve as a unit. The term holobiont was first coined by Lynn Margulis (48) and consisted of a simple and elegant way to explain how a host and its symbiont would evolve (49). This concept has been expanded, and it is well-accepted that a holobiont consists of a set comprised of the host and its associated microbial communities, i.e., the microbiota composed of the three domains of life, and viruses (50). According to this concept, the host (i.e., plant or animal) is subject to ecological and evolutionary pressures, so the entire community would evolve according to natural selection (51-53). This concept has been widely adopted, especially in the coral and human microbiome literature $(54,55)$, and it is relevant to understand its implications on human health. Understanding the relationships and interactions between microorganisms and parasites, such as helminths and protozoans, with host cells and tissues within a holistic approach is of paramount importance (49) and may provide practical solutions for challenging problems such as antibiotic resistance, allergies and asthma (56). This concept is tightly linked with the One Health framework, which is a multidisciplinary collaborative effort to achieve most appropriate health for people, animals and environment $(50,57)$.

The advances in DNA sequencing technologies and computational tools enabled us to explore in great detail the microbial communities and their ecological relationships on several times and space scales (58). This is a flourishing time for microbiome studies and a robust body of literature has already elucidated how environmental drivers shape freeliving and host-associated microbial communities (58). Several lines of evidence show that human health is tightly linked with the equilibrium of the commensal microbial community, ultimately holobiont homeostasis. The microbial biodiversity and the relationships and interactions among microbes lead to functional outcomes. Reducing diversity, usually by a dominant microorganism, promotes a more variable and less resilient microbiota, a phenomenon known as dysbiosis, which can alter the ecosystem services provided by the microbiota, leading to a disease state.

More specifically, for the scope of the present review, the mammalian gastrointestinal tract harbors a wide diversity of microorganisms. It is estimated that Homo sapiens DNA makes up only a small percentage of the overall DNA on and within the human body-far greater genetic contributions are derived from bacteria, fungi, viruses, archaea, and other microorganisms as part of a vast (and individually distinct) residential community collectively known as the human microbiome (48). Additionally, more than 100 trillion microorganisms, colonize the oral-gastrointestinal tract (59). The microbiota interacts and stimulates the host immune system by activating bacterial metabolism through biochemical pathways (60), mediated by diet, host and microbiota metabolites, and antimicrobial compounds (60). The commensal microbiota is essential not only for the use of nutrients through good digestion and resistance to infections by pathogens but also supports the regulation of the host immune system, influencing innate, and adaptive immune responses (61). Dysbiosis can lead to a disruption on immune homeostasis and, consequently, to diseases such as allergy, asthma, neurodegenerative disorders, autoimmune, cardiovascular, and metabolic diseases $(60,62)$.

\section{Host-Bacterial Interactions}

The presence of organisms/microbes in the human body is important to induce a proper immune response, including a regulatory mechanism that could even have a bystander effect of inflammatory conditions (63). The immune system is regulated by immune organs and cells, soluble cytokines, and cell receptors (64). The gut-associated lymphoid tissue is composed of three different lymphoid structures of the mucosa: immune cells present in the compartments of the intestinal epithelium, lamina propria, and Peyer's patches of the small intestine $(61,64)$. Commensal human host bacteria modulate the immune system through a bridge between epithelial cells and lymphoid structures (65). It has been previously described that microbiota can induce both Th17 and T regulatory (Treg) immune responses (66). The interaction with epithelial cells induces Th17 cell polarization and a positive regulation of antimicrobial proteins. Th17 cells are vital for protective host immunity and have been implicated in autoimmune disease development by producing the proinflammatory cytokines IL-17A, IL-17F, and IL-22 $(59,66)$.

Clostridia, segmented filamentous bacteria, Bacteroides fragilis, and other microorganisms can induce the development and/or activation of Treg cells by stimulating intestinal epithelial cells, lamina propria dendritic cells (DCs) and macrophages (59). However, it is unclear which molecular mechanisms commensal microbiota induce Treg cells in the gut $(67,68)$. Treg cells control autoimmune reactivity, suppress inflammatory responses, and maintain homeostasis of the microbiota (69). According to Kamada et al. (59), the reduction of Treg cells can increase the expansion of $\mathrm{CD} 4+\mathrm{Th}$ cells expressing commensal bacteria-specific $\mathrm{T}$ cell receptors (TCRs), leading to intestinal inflammation.

In fact, the mechanisms whereby commensal microbiota can modulate immune response is an area of increasing interest. In this context, the immune cells in the Peyer's patches are responsible for the surveillance of the intestinal lumen (70). Peyer's patches contribute to the generation of B cells, which, once activated, produce intestinal secretory IgA (sIgA) (64). IgA is the most abundant class of immunoglobulin produced in mucosal tissues, mostly the gut $(59,71)$. sIgA is essential for the neutralization of toxins and response to pathogens. It promotes intestinal barrier function and supports maintaining host-commensal mutualism. In addition, IgA is involved in determining the diversity and regulating the composition and function of the gut microbiota $(59,70)$. Innate lymphoid cells (ILCs), categorized into three subsets (groups 1, 2, and 3), help also with the homeostasis, control the composition of the microbiota, contribute to the resistance to pathogens and heal the gut $(59,64)$. ILC1s promote homeostasis through the production of IFN- $\gamma$, while ILC2s are activated by IL-25 (induced by commensal microbiota) to release amphiregulin (Areg), which is responsible for tissue repair, and IL-5/6, which has a role in the production of IgA by B cells (72). IL-22 induces the production of ILC3s, leading to mucus production, the release of the antimicrobial peptide, fucosylation (a type of glycosylation) 
of the proteins from the lumina and lipids that offer energy for the microbiota (72).

Some commensal bacteria, such as Clostridia strains, have been shown to suppress the immune response by promoting the differentiation of Tregs and IL-10 production in the gut $(65,73)$. The induction of colonic Tregs can depend on Clostridium cluster IV and XIV and the production of metabolites, such as shortchain fatty acids (SCFAs), which have immune and metabolic functions involved in the regulation of cellular processes $(74,75)$. SCFAs are metabolites synthesized by bacterial fermentation of indigestible carbohydrates, in the colon, and decomposition of dietary fibers $(61,76)$. Propionate, butyrate, and acetate are the most predominant SCFAs in the gut and enable Treg production $(73,75)$. Butyrate is involved in Treg differentiation by binding G-protein-coupled receptor 43 (GPR43), a receptor of SCFAs present in colonic T cells (76). Butyrate has also been shown to induce Treg cell differentiation via dendritic cells dependent on GPR109a (77). This metabolite also can regulate central steps of the eosinophil lifecycle and function (78), inhibit ILC2 proliferation and cytokine production likely through inhibition of GATA3 expression (79), inhibit nuclear factor- $\kappa \mathrm{B}(\mathrm{NF}-\kappa \mathrm{B})$ signaling via protein acetylation by a HDAC inhibitor (80) and limit the production of TNF by lipopolysaccharide (LPS)stimulated neutrophils (81) and peripheral blood mononuclear cells (66) (Table 1).

Escherichia coli trytophanase produces indole from tryptophan (94). This metabolite activate aryl hydrocarbon receptor, a transcription factor that induces expression of genes such as CYP4501A1, which cleans chemicals and toxins (95). Indole has an immunomodulatory function by maintaining the integrity of the enteral mucosa and promoting the epithelial barrier defense against pathogens by stimulating the production of anti-microbial peptides, mucins, and proliferation of intestinal goblet cells (62) (Table 1).

Polysaccharide produced by Bacteroides fragilis, a species of gut microbiota, was described to conduct systemic immunological maturity and could restore the balance between Th1 and Th2 cells and CD4+ T cell deficiency in germ-free mice $(65,66,74)$. B. fragilis triggers toll-like receptors to create a symbiosis between the host and microbiota and affects the differentiation and development of $\mathrm{T}$ cells (74). Lactobacillus reuteri is a Gram-positive facultative anaerobic bacterium that also resides in the gut microbiota. This microorganism has many benefits as a probiotic, such as reducing infection, influencing the integrity of gut mucosa, and modulating the host's immune responses (96). L. reuteri has a role in protecting lung infections, stimulating the production of gut granulocyte-macrophage colony-stimulating factor, which promotes clearance of pathogens by alveolar macrophages $(74,96)$.

\section{Host-Fungus and Viruses Interactions}

Although bacteria are a main component of the human microbiota, there are other organisms also composing the holobiont such as fungi, viruses, and multicellular parasites that are also important for a good balance, with potential effects on human health. The most-reported fungi in the intestines of mice and humans include Saccharomycetes (Candida and
Saccharomyces spp.), Eurotiomycetes (Aspergillus and Penicillium spp.), Tremellomycetes (Cryptococcus and Trichosporon spp.) along with Cladosporium, Wallemia, and Malassezia spp. (97).

Candida albicans interacts with intestinal epithelial cells through some events, including adhesion, invasion, damage, and apoptosis (98). This interaction can lead to superficial overgrowth and epithelial invasion, followed by disease and immune activation (82). The Candidalysin, a cytolytic peptide toxin released by C. albicans, induces proinflammatory cytokines, chemokines and antimicrobial peptides of epithelial cells that are necessary for the recruitment of immune cells, via MAPK signaling, specifically the p38 pathway, resulting in the activation of the AP-1 transcription factor c-Fos, and the ERK1/2 pathway, leading to the activation of MKP1 (MAPK phosphatase 1), which regulates the immune response (82).

Aspergillus fumigatus produces a variety of precursors of toxins such as gliotoxin, which represses IFN- $\gamma$ responses and induces neutrophil apoptosis through inhibition of NF- $\kappa$ B, a transcriptional regulator of the host proinflammatory response (99); and fumigaclavine $C$ that down-regulates Th1 cytokines, by binding to IFN-x receptor 1 (IFN-x R1) (100) and induces host cell apoptosis via caspases-3,-8, and-9 $(83,101)$.

In addition to bacteria and fungi, the intestinal virome is composed of DNA and RNA viruses and includes eukaryotic viruses, endogenous retroviruses and bacterial viruses (102). According to (84), eukaryotic viruses and bacteriophages can stimulate changes in the immune response. Eukaryotic virus by altering the hematopoiesis or immune activation, improving a secondary infection. Bacteriophages by stimulating the production of inflammatory cytokines and type I interferon. These changes in immune responses can contribute to inflammatory diseases. In this review, we will focus in unicellular and multicellular organisms leading to immune modulation.

\section{Host-Helminths Interactions}

Moreover, the different life cycle stages of helminths and protozoa challenge host immune responses to recognize and respond to different antigens. Distinct pattern recognition receptors members participate in the recognition of these parasites and are responsible for driving the TCD4 + cells polarization. Many molecules secreted by adult intestinal worms known as "excretory/secretory antigens" (ES) can stimulate different effects on the host's immune cells. The helminth ES products activate basophils, eosinophils, mast cells, innate lymphocyte T cells 2 (ILC2) and TCD4 + cells and drive the production of innate and adaptive cytokines. Different classes of lipids extracted from schistosome eggs and adult worms have been able to stimulate the production of several inflammatory cytokines (IL-6, IL-8, IL-10, IL-12, TNF- $\alpha$ ). Schistosomal lysophosphatidylserine through TLR2 stimulates activation of dendritic cells with subsequent development of IL10 producing Treg cells (85) and Ascaris lumbricoides derived phosphatidylserine containing preparations in the presence of interaction between TLR4 and LPS induced TLR2 with activation of $\mathrm{TH} 2$ response (91).

Schistosomal-Derived Lysophosphatidylcholine in vivo was able to induce cytokine production and eosinophil 
TABLE 1 | Summary of the main products (molecules) from holobionts with immunomodulatory potential and biological activities in the host.

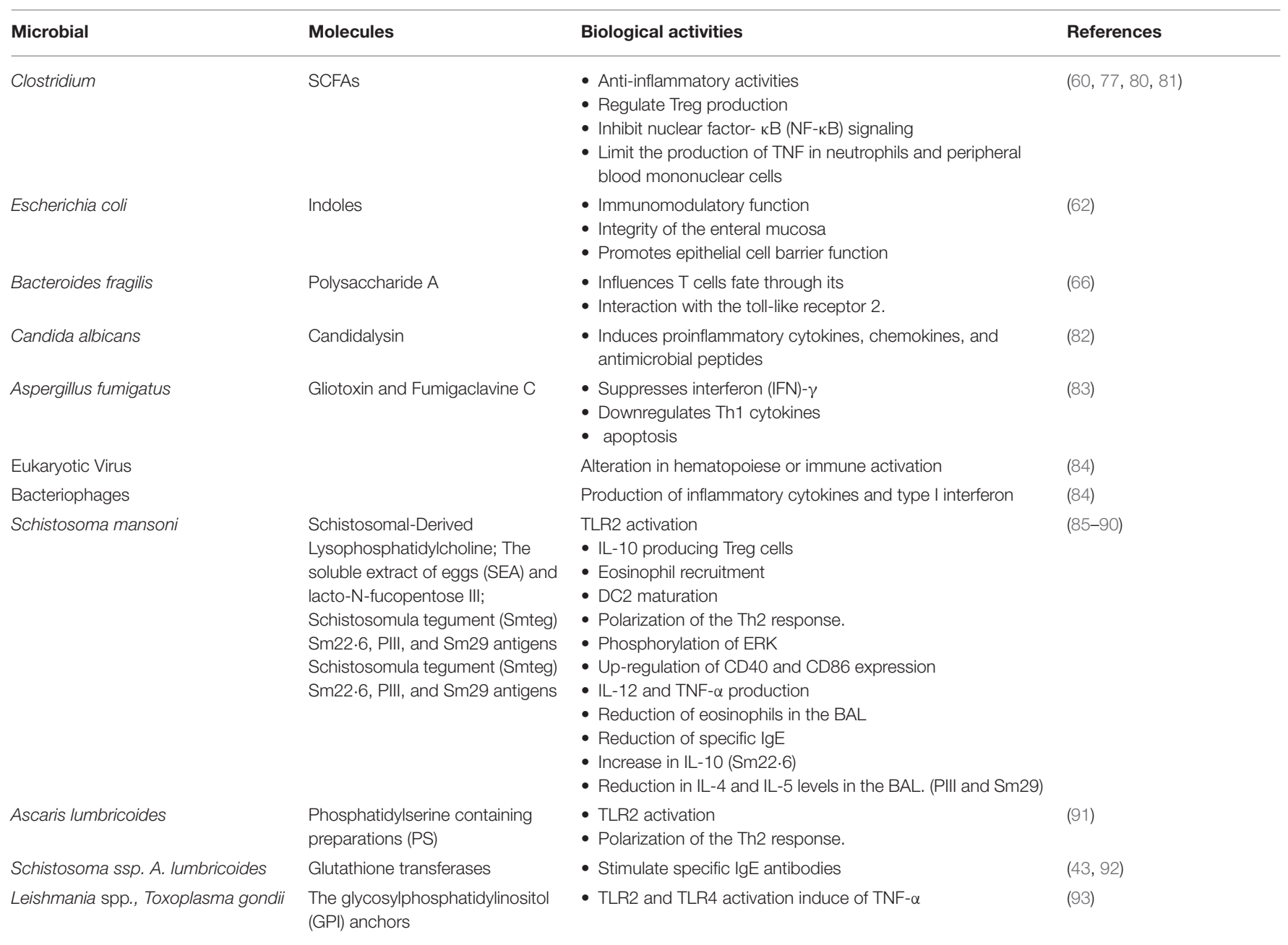

recruitment potentially through TLR2 recognition (86). Lysophosphatidylcholine participates in the recruitment of eosinophils (85) IL-5 and IL-3 stimulate eosinophilia, and recruitment is mediated mainly by chemoattractant CCL11 and CCL26 (eotaxins). Activation of eosinophils results in degranulation of chemical mediators such as Matrix metalloproteinases, cysteinyl leukotrienes, major basic protein and others (103). It has been shown that patients with Schistosoma infection exhibit a higher concentration of CCL3, CCL5, and CCL11 in plasma compared to uninfected individuals. These chemokines favor granulocyte recruitment, granulomatous response against egg antigens $(104,105)$.

Antigens from Schistosoma mansoni, Sm22.6 (soluble protein from the tegument of $S$. mansoni), PIII (multivalent antigen from the S. mansoni adult worm) and Sm29 (a membranebound glycoprotein from the adult worm tegument) were tested in a murine model of induced airway inflammation and showed immunomodulatory ability. These antigens induced a reduction in the number of eosinophils in bronchoalveolar lavage (BAL) and lower levels of specific IgE. In addition, Sm22.6 was associated with an increase in IL-10 while PIII and Sm29 showed a reduction in IL-4 and IL-5 levels in the BAL (90).

The soluble extract of Schistosoma mansoni eggs and lacto$\mathrm{N}$-fucopentose III (carbohydrates group in S. mansoni) has been associated with DC2 maturation and induction of the Th2 response dependent on recognition by TLR4, as well as induces phosphorylation of $\operatorname{ERK}(87,88)$. In addition, schistosomula tegument (Smteg) can induce up-regulation of CD40 and CD86 expression and production of proinflammatory cytokines, such as IL-12 and TNF- $\alpha$, and such activation is TLR4-dependent (89).

The glutathione transferases from helminths (Schistosoma ssp. and A. lumbricoides) stimulate specific IgE antibodies (92, 106) The glycosylphosphatidylinositol anchors from protozoan (Leishmania spp., Toxoplasma gondii) is involved in the activation of cells of lymphoid and myeloid lineage, such molecules are recognized by TLR2 and TLR 4 with activation of NF- $\kappa \mathrm{B}$ and subsequent induction of TNF- $\alpha$ in murine macrophage cells (93).

The secretion of ES products from hookworms induces activation of ILC2s and tolerogenic dendritic cells, followed by increased expression of molecules associated with tolerance and 
reduced expression of co-stimulatory molecules with expansion of Treg cell numbers in the gut and suppresses Th17 cell, this implies a decrease in inflammation and proliferative capacity of the parasite $(107,108)$. Interestingly, the Howkworms' tolerance ability was demonstrated in experimental hookworm infection in patients with celiac disease, Necator americanus infection suppressed gluten-induced IFN $\gamma$, IL-17, and IL-23 expression and increased the expression of IL-10, TGF $\beta$, and IL-22 in the gut $(107,109)$.

It has been shown that infection with geohelminths ( $A$. lumbricoides, Trichuris trichiura, hookworm) induces IL-10 and a higher mRNA expression of the Foxp3, PD-1, and regulatory molecules suppressor of cytokine signaling (SOCS) (-3) (110), reinforcing the immunomodulatory capacity of geohelminths. In addition, many of the ES components have pleiotropic immunomodulatory properties.

Taken together, it is possible to see that a balanced holobiont is necessary to maintain homeostasis. Any alteration in this environment can lead to dysregulation of the immune system and metabolism. Further studies are needed to exactly describe how holobionts changes regulate the host immune system, and which changes in its composition is associated with specific diseases.

\section{THE RELATIONSHIP BETWEEN THE SHIFTS IN HOLOBIONT COMMUNITY'S COMPOSITION WITH ASTHMA AND ALLERGIES}

Exposures during the peri- and post-natal periods are critical for the host's immune homeostasis, reflecting immune maturation, the development of immune tolerance mechanisms, and susceptibility to disease, also known as the first "window of opportunity" (111). This exposure includes fetal environment conditioned to the individual to the mother's lifestyle, type of delivery, diet, use of antibiotics, exposure to other children and animals, and contact with parasites and environmental microbes (112). Studies have reported that exposure to specific immunostimulatory molecules (from helminths and bacteria mainly) in childhood could reduce or block allergic disease development or progression (113). In embryonic development the immunological regulation of pregnancy is complex and an increased production of Th2 cytokines is observed, along with decreased production of Th1 cytokines. In addition, TGF- $\beta 1$ appears to be involved in the differentiation of the trophoblast being an important inducer of regulatory T cells (CD4 + CD25 + ) and Th17 cells, this seems to be essential for avoiding fetal allorejection $(114,115)$. Microbial exposures in childhood determine factors in modulation and gradual replacement for $\mathrm{T}$ cells and cytokines other than Th2 (116).

Moreover, universal initiatives seeking to improve the population's health conditions, such as immunization in children, improved hygiene and sanitation, access to clean water, indiscriminate use of antibiotics and anti-parasitic drugs, have been implied in reducing opportunities of microorganism's exposure/infections in early childhood with decreased Th1 responses and or decreasing Treg activation and polarizing the immune response to the Th2 profile, breaking homeostasis. Changes in the exposure of antigen patterns, including proteins released from environmental particles or infections in childhood, can impact the diversity of commensal microorganisms that make up the microbiota (117).

The use of antibiotics by mothers during pregnancy is associated with a child's asthma risk, promoting an imbalance between commensal, and pathogenic bacteria (118). Changes in the colonization of the lung microbiota of neonatal mice have $(119,120)$ been associated with decreased aeroallergen responsiveness induced by Helios- regulatory $\mathrm{T}$ cells (HeliosTreg cells) activated depending on interaction with programmed death-ligand 1 early in life, widely known as a regulator of allergic responses. Imbalance in the formation of these cells implies increased susceptibility to atopy in adulthood (119). Likewise, the altered composition of the airway microbiota is often found in asthmatic patients $(120,121)$. This could be explained partially by differences in environment.

\section{Rural vs. Urban}

For instance, the prevalence and severity of asthma differ between urban and rural areas. An agricultural environment has been associated as a protective factor against the development of asthma, hay fever, and atopic sensitization in children $(12,122)$. An explanation would be associated with concentrations of endotoxin significantly higher in rural homes than in urban centers (123). Exposure to higher levels of endotoxin and other bacterial components in early childhood can play a protective role against allergies and asthma (123). The endotoxin constitutes the membrane of gram-negative bacteria, inducing the Th1 response by stimulating cytokines such as IL-12 and IFN-r (12). In addition to that, helminth infections caused by Ascaris lumbricoides, Trichuris trichiura, are more prevalent among children living in areas of the rural tropics in poverty and poor access to clean water and sanitation (124).

\section{Helminths vs. Asthma/Allergies}

Helminths and allergic asthma induce similar immune responses, including elevated serum IgE, systemic eosinophilia, and cytokines such as IL-4, IL-5, IL-9, and IL-13, the hallmark of an immune Th2 response (125). Additionally, basophils, mast cells, neutrophils and innate lymphoid cells are involved (126). Interestingly, infections by parasite species such as A. lumbricoides, Schistosoma mansoni, Strongyloides stercoralis, and $T$. trichiura, have been associated with a reduction in airway allergic inflammation (34) with decreased Th1 responses (Table 2). The immunomodulatory ability of geohelminths to reduce susceptibility to allergies in humans has been recognized, and it is related to the immune-regulatory network, including helminth-derived products. Recombinant proteins of S. mansoni were associated with an increase in IL-10 and TGF- $\beta$, an increased frequency of regulatory $\mathrm{T}$ and $\mathrm{B}$ cells, and a reduction in the frequency of activated T lymphocytes that produce IL-4 and IL-13 in individuals with severe asthma and animal models $(142,143)$. In addition, $T$. trichiura infection appears to modulate the immune response among asthmatics, with some studies 
TABLE 2 | Summary of the immunomodulatory effects of some halobiont's organisms on asthma and allergy.

\begin{tabular}{|c|c|c|}
\hline Holobiont & Immunomodulatory effects & Consequences \\
\hline Schistosoma mansoni & $\begin{array}{l}\uparrow T N F-a \text { and IFN-g in acute phase } \\
\uparrow I L-10 \text { in chronic phase }\end{array}$ & $\begin{array}{l}\text { Prevent against the development of allergies and asthma } \\
(32,34) \\
\text { Down-modulate the inflammatory response in murine } \\
\text { model of ovalbumin (OVA)-induced airway inflammation } \\
(90)\end{array}$ \\
\hline Ascaris lumbricoides, & $\uparrow I L-4, I L-5$, and IL-10 & $\begin{array}{l}\text { Ascaris lumbricoides eggs was associated with an } \\
\text { increased prevalence of asthma (124) } \\
\text { Reduced risk of wheeze (127) } \\
\text { Anti-A lumbricoides IgE antibodies were associated with } \\
\text { risk of wheezing in atopic children and atopia (36) }\end{array}$ \\
\hline Trichuris trichiuria & $\begin{array}{l}\text { Modulation of pro and anti-inflammatory cytokine (35) } \\
\downarrow \text { TNF- } \alpha \text { and IL-6 levels among asthmatics infected } \\
\uparrow \text { IL-10 }\end{array}$ & $\begin{array}{l}\downarrow \text { allergen skin test reactivity (33) } \\
\text { Positively associated with wheezing (36) }\end{array}$ \\
\hline Helicobacter pylori & $\begin{array}{l}\text { Th1 polarization } \\
\downarrow T h 2 \text { response } \\
\uparrow(\text { IFN)- } \gamma, I L-12, I L-18, I L-23(128)\end{array}$ & $\begin{array}{l}\text { Negative association between } \mathrm{H} \text {. pylori infection and } \\
\text { asthma, eczema, and rhinitis (128) }\end{array}$ \\
\hline $\begin{array}{l}\text { Hookworm (Ancylostoma } \\
\text { duodenale and Necator } \\
\text { americanus) }\end{array}$ & $\begin{array}{l}\text { Induction of IL-25 and ILC2s (129) } \\
\uparrow \operatorname{lgG} 1, \operatorname{lgG} 4, \text { and } \lg E \\
\text { Expansion of Treg cell numbers in the gut }(107,108)\end{array}$ & $\begin{array}{l}\text { Protect against wheezing, asthma, and allergic diseases. } \\
\text { Reduction in risk of wheeze (130) }\end{array}$ \\
\hline Toxoplasma gondii & $\begin{array}{l}\text { Induces IL-10 production, IL-27, and activity of lipoxins } \\
(131,132) \text {. }\end{array}$ & $\begin{array}{l}\text { Protective effect against atopy (133) } \\
\text { Suspend the development of airway inflammation and } \\
\text { atopy in mice (133) } \\
\text { Decrease in specific IgE for Dermatophagoides } \\
\text { pteronyssinus (134) }\end{array}$ \\
\hline Toxocara spp. & $\begin{array}{l}\uparrow \text { levels of total lgE } \\
\text { Cross reactivity with aeroallergens }\end{array}$ & $\begin{array}{l}\text { Positive skin tests to allergens, and asthma prevalence } \\
\text { and morbidity }(135,136)\end{array}$ \\
\hline Bifidobacterium & Stimulating IL-10 or IL-12 synthesis & $\begin{array}{l}\text { Protective factor for high risk of allergic asthma and } \\
\text { atopic dermatitis in children from Turkey (137) }\end{array}$ \\
\hline Bacteroides fragilis & Stimulate Th2 cytokines by biding TLR2 & Risk factor in children with a positive API (138) \\
\hline Penicillium & High counts in patients with atopy & Risk factor for atopic asthma $(139,140)$ \\
\hline Aspergillus fumigatus & Decrease the expression of GCR & $\begin{array}{l}\text { Aggravate airway hyper-responsiveness and increase the } \\
\text { level of TLR2 (141) }\end{array}$ \\
\hline
\end{tabular}

个increase; $\downarrow$ decrease.

reporting a risk association for asthma among infected people and positively associated with wheezing $(33,35,36)$.

Maternal soil-transmitted helminths (STH) infections can sensitize the individual still in the fetal phase. Cooper et al. (144) reported a strong association between Maternal STH infections during pregnancy (mainly moderate to chronic A. lumbricoides infection) and childhood STH infections. During pregnancy, infected mothers have an increased number of CD $4+\mathrm{T}$ cells and production of IL-10 in cord blood from newborns demonstrating immunomodulation mediated by parasite antigens $(145,146)$. In the same study, poor hygiene conditions, with the prevalence of STH infections, were not associated with reduced eczemaasthma-rhinitis symptoms (144). Co-exposure to mites and Ascaris lumbricoides in the context of low worm burdens promotes allergic sensitization and asthmatic symptoms by increasing parasite-specific IgE production, mite-specific and mite-parasite cross-reacting IgE antibodies, observed mainly in urban areas, once in rural areas the exposure to helminths tends to be chronic (40). A. lumbricoides extract was associated with inhibition of pulmonary eosinophilia in mice sensitized with ovalbumin (OVA) and a decrease in allergic inflammation independent of IL-10 (147) (Table 2). In contrast, Anti-A. lumbricoides $\operatorname{IgE}$ (but not active infection), were associated with risk of wheezing in atopy in atopic children (36).

\section{Viruses and Protozoans vs. Asthma/Allergies}

Some viral and protozoan infections have been associated with decreased reactivity to skin prick tests for aeroallergens (148, 149) and asthma (150). The host's defenses against viruses are marked by a predominance of the Th1 response and interaction with different Toll-like receptors with probable biological and immunomodulatory effects on Th2 responses. Toxoplasma gondii infection has been reported to suspend the development of airway inflammation and atopy in mice (133) and induces IL10 production, IL-27 and activity of lipoxins (131, 132). In addition, a negative association was reported between $T$ gondii seropositivity and specific IgE to Dermatophagoides pteronyssinus (134). Hepatitis A virus (HAV) exposure has been inversely associated with allergies (151). In the United States, positive serology for HAV was associated with a lower chance of developing hay fever and asthma and skin reactivity to airborne allergens (152). In Turkey, the prevalence of atopy was lower among individuals with positive serology for HAV and hepatitis 
B virus (anti-HAV IgG, HBsAg, anti-HBc IgG) (153). The accumulated infection burden, considering HAV, herpes simplex virus, Epstein-Barr virus, Cytomegalovirus, Helicobacter pylori, and Toxoplasma gondii ( $>3$ microbes), was associated with a protective effect against atopy $(149,153)$. According to Amedei et al. (128) H. pylori infection was negatively associated with asthma, eczema and rhinitis and induces Th1 polarization (Table 2). Moreover, BCG vaccination at an earlier age was associated with a decreased risk of atopy in children without a family history of asthma and atopy (154). However, there are controversies regarding some types of vaccines $(155,156)$.

\section{Bacteria vs. Asthma/Allergies}

A study (157) from the Copenhagen Prospective Study on Asthma in Childhood has shown that the lack of development of the gut microbiome in the first year of life is the determinant to the occurrence of childhood asthma, increasing asthma risk. The lower number of Lachnospiraceae and Ruminococcaceae genera was observed in asthmatic children and was associated with allergic wheezy phenotype (157). The production of SCFAs was suggested to be associated with asthma development in a study of high vegetable fiber intake by children from Manitoba Prospective Cohort Study of Allergy, Genes and the Environment, acting as a protective factor against to airway hyperresponsiveness $(158,159)$. Bifidobacterium longum has been described influencing the prevalence of allergic disease being a protective factor for allergic asthma and atopic dermatitis in children from Turkey (Table 2) (137). In contrast, Bacteroides fragilis count was significantly higher in children with a positive Asthma Predictive Index as compared with those negative (138). It seems that Bacteroides species maybe stimulate Th2 cytokines and some studies have found an association between this genera and higher IgG in children with allergies (138) (Table 2).

\section{Fungus vs. Asthma/Allergies}

Skin-test for fungal allergens is usually characterized with the presence of immediate cutaneous hyperreactivity or positive results for specific IgE antibodies to fungal antigens and has been related to be especially common in patients with life-threatening asthma (139, 160). Aspergillus, Alternaria, Penicillium, Cladosporium, and Trichophyton, have been described to be associated with exacerbation and severity of asthma (139). Penicillium species was higher in patients with atopy compared with healthy control subjects, suggesting to be a risk factor for atopic asthma since this genera is one of the most common fungi related to allergic asthma exacerbations among adults (Table 2) (140, 161). A study using rats with asthma shows that Aspergillus fumigatus may decrease the expression of glucocorticoid receptor aggravating airway hyper-responsiveness and increase the level of TLR2, involved in airway inflammation (141) (Table 2).

The immune response in the context of asthma and atopy as well as its development, differentiation of cell subtypes and expression of receptors and cytokines are influenced by exposures to holobionts. This immunological modulation is often accompanied by epigenetic changes. In part, such modifications that allow such plasticity of immune responses, also promote homeostasis through the balance of adaptive immune responses in certain conditions and are responsible for the maintenance and intensification of Th2 responses, increasing the risk for allergic diseases and other inflammatory diseases.

\section{EPIGENETIC MECHANISMS: BASIC CONCEPTS}

Currently, epigenetics can be defined as changes above the DNA without changing the nucleotide sequence (162). Different mechanisms of epigenetic regulation have been described, such as DNA methylation, histone modifications and non-coding RNAs. Since the first Waddington epigenetics works (163, 164), many studies have been conducted to determine the influences of epigenetics in several conditions. The epigenetic mechanisms are widespread in the different cell types of the human body, including cells that participate in an immune response pathway directly involved in the etiopathogenesis of asthma and other allergic diseases. Understanding the impact of epigenetic changes on the normal and abnormal functioning of these cells, therefore, is an important piece to compose the complex puzzle that allergic diseases represent. Bellow, are described the main mechanisms of epigenetics-induced changes in gene expression.

\section{DNA Methylation}

DNA methylation is the addition of a methyl group $(\mathrm{CH} 3)$ to a cytosine by DNA methyltransferases, generating 5-methylcytosine (165). Promoter regions of genes have a large amount of CpG (cytosine-phosphate-guanine), known as CpG islands, that when methylated prevents the binding of transcription factors and represses gene expression (166).

Several factors can contribute to DNA methylation changes, such as aging, environmental exposure, cell type, and age. These modifications can be passed through cell division through either mitosis or meiosis (167). Recently, many epigenomewide association studies (EWAS) have described the association between DNA methylation and asthma, and several genes were identified, including EPX, IL4, IL5RA, PRG2, SIGLEC8, CLU, AP2A2, and KCNH2 (168-170).

\section{Histone Modifications}

Histone is a protein involved in the organization of chromatin and regulation of gene expression. They are grouped into 8 subunits, two of each $\mathrm{H} 2 \mathrm{~A}, \mathrm{H} 2 \mathrm{~B}, \mathrm{H} 3$, and $\mathrm{H} 4$ forming an octameric nucleosome where the DNA coils. Histone $\mathrm{H} 1$ is associated with this complex and stabilizes the chromatin structure. Some modifications can occur in the $\mathrm{N}$-terminal tails of histones, including acetylation, methylation, ubiquitylation, and phosphorylation (171).

Histone acetylation occurs when acetyltransferases add lysine residues to histone tails. Histone acetylation increases DNA access and facilitates the process of transcription, increasing gene expression. Previous studies reported that H3K4me3 and H3K27me3 were associated with T helper cell differentiation and IL-5 expression (172), and higher histone 3 acetylation levels at the IL13 locus were associated with higher protein levels of IL13 (173). 
Methylation in histones is performed by methyltransferases and usually occurs at lysine $(\mathrm{K})$ or arginine $(\mathrm{A})$ residues and can increase or decrease gene expression depending on the modified residue. For instance, inactivation can occur by methylation on $\mathrm{H} 3 \mathrm{~K} 9, \mathrm{H} 3 \mathrm{~K} 27$, and $\mathrm{H} 4 \mathrm{~K} 20$, while activation occurs by methylation on $\mathrm{H} 3 \mathrm{~K} 4$ and $\mathrm{H} 3 \mathrm{~K} 36$ (174).

\section{Non-coding RNAs}

Non-coding RNAs are a group of RNAs that do not encode proteins but can play an important role in the regulation of gene expression acting at the post-transcriptional level (175). Regarding size, RNAs with regulatory functions are divided into short non-coding RNAs (siRNAs, miRNAs and piRNAs) and long non-coding RNAs (lncRNAs) (176). They can silence genes through the RNA interference pathway and modulate several biological processes, including immunological functions (177).

\section{SHAPING IMMUNE RESPONSES THROUGH EPIGENETICS MECHANISMS: REGULATION OF CYTOKINE GENE EXPRESSION, TRANSCRIPTION FACTORS, AND REGULATION OF IMMUNE RESPONSES IN ASTHMA AND ALLERGY}

The epigenetic mechanisms previously described are present in the different contexts and cell types of the human body, including driven immune cell pathways directly involved in the etiopathogenesis of asthma and other allergic diseases. Understanding the impact of epigenetic changes on the normal and abnormal functioning of these cells, therefore, is an important piece to compose the complex puzzle that allergic diseases represent. Some advances in this direction have recently been achieved. Thus, epigenetic modifications play a role in regulating the expression of cytokines related to $\mathrm{T}$ cell differentiation and transcription factors (178). The development of cell types and, consequently, the specificity of immunological responses occur through internal stimuli or driven by stimulatory molecules of microorganisms. They act on surface receptors such as TLR signaling, signal transduction proteins, and lineagespecifying transcription factors, promoting intracellular events. Even the development of $\mathrm{T}$ lymphocytes and maturation for helper $(\mathrm{CD} 4+)$ and cytotoxic (CD8+) cells are influenced by epigenetic control. This promotes $\mathrm{CD} 4+$ silencing in $\mathrm{CD} 8+$ thymocytes and the development of T helper cell subsets (Th1, Th2, and Th17) accompanied by epigenetic changes $(179,180)$. Epigenetic changes have also been linked to the activation and polarization of macrophages (M1/M2 phenotypes) (181).

Allergic diseases, e.g., asthma, result from a strong interaction of genetic and environmental components with remarkable phenotypic heterogeneity. This heterogeneity of asthma can be partially explained by dysregulated epigenetic mechanisms correlated with environmental exposures, pharmacological treatments, and airway inflammation and function (182). There is evidence that the induction of Th2 cells, maintenance, and the resurgence of memory Th2 cells are controlled by epigenetic regulation since this induction is mediated by signal transducer and activator of transcription 6 and the consequent production of the Th2 cytokine profile (183). Hypermethylation in GATA3 CpG loci was associated with a decreased risk of asthma at birth (184), and hypomethylation of IL-13 and interleukin 5 receptor subunit alpha (IL5RA) was associated with an increased risk of asthma in teenagers (169).

Epigenetic mechanisms are essential in controlling gene expression or silencing and the consequent balance of Th1/Th2 responses. Corroborating the principle that Th1/Th2 imbalance is involved in the pathogenesis of asthma and atopy, experimental studies in mice showed hypermethylation in the IFN-r gene promoter in TCD4+ cells, leading to the silencing of the IFNG gene (Th1 pattern) (185). During initiation of a Th2 immune response, an increase in histone acetylation was observed at the Th2 cytokine loci. It has been demonstrated that the IL4 and IL13 genes are hypomethylated in asthmatic patients, critical genes in amplifying the Th2 response (186).

A balance of histone deacetylase (HDAC) and histone acetyltransferase (HAT) activity has been considered to regulate gene expression. Reduced HDAC expression was observed among adults with severe asthma compared to mild asthma (187). In atopic asthmatic children, a relationship was found between HDAC/HAT activity and increased histone acetylation, and the degree of acetylation was associated with an increase in bronchial hyperresponsiveness (188).

miRNAs have also shown an essential role in the inflammatory response of asthma. Studies have shown that miR-155 and miR221 are associated with modulation of the Th2 response (189) and hyperproliferation of airway smooth muscle in asthmatic patients, respectively (190). In the asthma context, non-coding RNAs have been observed as markers of disease diagnosis, phenotypes, and response to treatments. For example, a negative correlation between the levels of miR-323-3p and IL22 and IL17 was observed in PBMCs from patients with asthma, suggesting that non-coding RNA acts as negative feedback in the production of these cytokines influencing the immune response of these individuals (191). Moreover, elevated levels of miRNA-21 in the peripheral blood of children with asthma were identified, suggesting that this non-coding RNA may be a biomarker in the diagnosis of asthma (192). Furthermore, high expression of microRNA-155 and decreased expression of Let-7a were observed in the plasma of asthmatic patients and were associated with the degree of asthma severity, suggesting that these markers can be used both in diagnosis and in the prediction of the severity of disease (193).

In the context of regulatory $\mathrm{T}$ cells (Tregs), cells that play a substantial role in immune homeostasis through mechanisms of tolerance and immune de-activation during a regular immune response and suppression of a self-destructive immune response, the repressive phenotype of Tregs is conferred, in part, by the expression of Forkhead box protein 3 (FOXP3) (194). Hypermethylation of $\mathrm{CpG}$ islands in the promoter region in the FOXP3 locus impacts transcriptional silencing and consequent reduction in Treg cell function. Air pollutants have been recognized as acting on epigenetic changes. Increased exposure to polycyclic aromatic hydrocarbons has been associated with an increase in DNA methylation at the FOXP3 locus in peripheral 
blood mononuclear cells and elevated total IgE with significant effects on asthmatics (195). Furthermore, an increase in FOXP3 DNA methylation has been associated with an increased risk of asthma and persistent wheezing (196).

Figure 1 shows different factors shaping asthma and allergy, such as environmental factors, epigenetic changes, and exposure to holobionts components which can be modulated by disturbances in the homeostasis.

\section{EPIGENETIC CHANGES ASSOCIATED WITH HOLOBIONT INTERACTIONS}

Since immune dysregulation is linked to allergies and asthma through the lack of certain environmental exposure, one could think that potential epigenetic mechanisms may play a role in this phenomenon. A question raised by these new findings is at "what point in the development of the human being the epigenetic mechanisms could act to drive the maturation of the immune system in early life?." In this sense, in recent years, the hygiene hypothesis has been expanded to encompass the potential effect of prenatal exposure to microbial agents on modulating the individual risk of asthma and other allergic diseases (115). Although some evidence in this regard was already available through epidemiological studies that assessed the impact of maternal microbial exposure on the risk of developing allergic conditions in the offspring (116), the elucidation of the molecular mechanisms underlying these processes has been a relatively new and fascinating field of investigation.

Alterations in the gut microbiota, called dysbiosis, is related to infections and inflammatory diseases and comes with irregular immune responses, e.g., particular inflammatory cytokines $(66,75)$. Changed gut microbiota can also increase the production of NK-K-B and TNF- $\alpha$ and the overexpression and activation of Th1 and Th17 cells (197). Studies have shown that changes in the gut bacterial composition and the production of its metabolites can influence epigenetic levels, such as reducing methylation and inhibiting histone deacetylases (197). Specifically, the metabolites influencing epigenetic enzyme activity are a substrate needed for epigenetic changes (197). For example, Butyrate, a metabolite from microbiota, can also inhibit HDAC, increasing the expression of FOXP3 through the acetylation of histone $\mathrm{H} 3$ in the promoter and enhancing Treg generation (164).

One of the first mechanistic studies on the allergoprotective effects of maternal exposure to microbes used a mouse model with the farm bacterium Acinetobacter lwoffii (198). In this study, the protective effect for allergic airway inflammation (AAI) in the offspring was dependent on maternal TLR signaling, since this protection was abolished when mothers were knocked out for multiple TLR genes. The authors also demonstrated that the immune dampening observed in the progeny of pregnant mice was not due to microbial components able to pass the fetus-maternal interface and directly activate the developing fetal immune system. This last observation suggests the possible involvement of epigenetic factors operating in the fetuses of mothers exposed to Acinetobacter lwoffii. Indeed, another study by the same group reported epigenetic changes in Th1/Th2 cytokine genes in offspring from pregnant mice exposed to A. Iwoffii (199). While the IFN $\gamma$ promoter on CD4+ T cells exhibited significant protection against the loss of histone 4 (H4) acetylation, with the consequent increase in IFN-r expression in OVA-induced AAI, the IL4 promoter showed a significant decrease in $\mathrm{H} 4$ acetylation and diminished gene expression. A protective effect against induced AAI has also been shown in the progeny of pregnant mice exposed to Helicobacter pylori extracts (200). An epigenetic consequence observed in the offspring was the enhanced demethylation of the regulatory $\mathrm{T}$ cell-specific demethylated region in Foxp3+ Treg cells. Intriguingly, this protective effect extended to the second generation (F2) of mice exposed to H. pylori antigens during pregnancy, with both sexes exhibiting similar levels of protection. This indicates that the epigenetic changes in the offspring induced by transmaternal exposure to $H$. pylori may extend to chromosomal loci other than just the TSDR linked to the $\mathrm{X}$ chromosome. The transfer of allergoprotective effects during the prenatal phase through maternal infection with the helminth Schistosoma mansoni has also been previously investigated in experimental models of AAI in mice (201). Interestingly, this protective effect was dependent on the stage of the immune responses to $S$. mansoni in the females at the time of mating. While the offspring of the mothers mated during the Th1 and regulatory phases showed protection against OVAinduced AAI, those born to mothers mated during the Th2 phase showed an exacerbation of the allergic inflammatory response compared to the controls. The authors also demonstrated that the protective effect of transmaternal exposure to $S$ mansoni was mediated by maternally produced IFN- $\mathrm{x}$ and not by the transfer of helminth antigens to the fetus. Potential epigenetic changes in the offspring associated with the protective immune phenotype, however, were not further investigated and remain to be clarified (202).

In humans, data on epigenetic changes induced by pre- or post-natal exposure to microbial agents and their relationship to asthma and other allergic conditions are still scarce. A pilot study evaluated the effect of maternal exposure to the farm environment on offspring epigenetic changes for genes known to be associated with asthma and allergies (203). Significant differences between non-asthmatic children born to mothers exposed to the farm environment and asthmatic children born to unexposed mothers were observed for the methylation pattern of the ORMDL3 and STAT6 genes in cord blood. In a recent study, Lund et al. (204) reported that changes in the methylation pattern in chromosomal previously linked to asthma, such as the SMAD3 promoter at $15 \mathrm{q} 22.33$ and intronic regions of the DDO/METTL24 genes at 6q21, were associated with atopic asthma in children with early rhinovirus-induced wheezing. In turn, DNA methylation changes linked to the prostaglandin D2 synthase gene were associated with non-atopic asthma in children with rhinovirus etiology at the first severe wheezing episode (204). This suggests that the epigenetic changes triggered by the same microbial agent may differ according to the specific phenotype of asthma or other allergic diseases, which needs to be further investigated in the future. 




FIGURE 1 | Interaction between multiple environmental exposures and epigenetic changes: impact on immune-mediated diseases. Polluting agents, environmental exposure, diet, age, drugs, and especially exposure to organisms (species of bacteria, fungi, protozoan, and helminths) act as inducers of epigenetic changes. Among the epigenetic modifications are DNA methylation and histone modifications. Histone acetylation increases DNA access and facilitates the process of transcription, increasing gene expression. The addition of a methyl group in $\mathrm{CpG}$ islands prevents the binding of transcription factors and represses gene expression. The interaction between environmental exposures and epigenetic variations begins in the embryonic period and continues throughout life, being strongly dependent on the environmental experiences/challenges of everyone. Such alterations can be highly modifiable by instantaneous adaptation to the environment or generate inheritable epigenetic patterns and consequences to offspring. Epigenetic mechanisms influence cell differentiation and polarization of immune responses, these events modulate biological responses, and can interfere with the development of different immune-mediated diseases such as cancer, asthma, allergies, autoimmune diseases.

Taken together, although several studies related to epigenetics of asthma and allergies have been published so far, very few initiatives explores the role of the environmental changes, in special, exposure to organisms such as bacteria, fungi, protozoan and helminths as important modulators of those biochemical changes in human DNA. Further studies are needed to better understand such associations. 


\section{FUTURE THERAPIES AS POTENTIAL MODULATORS OF EPIGENETICS CHANGES IN ASTHMA AND ALLERGIES: OBSERVATIONS AND FUTURE PERSPECTIVES}

The usual immunotherapy and pharmacological therapy in the treatment of asthma and allergies act in the modulation of immune responses, with a focus on reducing inflammation and increasing immunological tolerance. This immunological modulation is almost always accompanied by epigenetic changes. It is even possible to distinguish different epigenetic signatures between untreated individuals and individuals under treatment (205).

The use of inhaled corticosteroids (ICS) in the management of moderate to severe asthma is recommended by asthma management guidelines (206) and several studies have shown that corticosteroids are potent epigenetic modifiers (207209). Children with better response to corticosteroids have been shown to have hypermethylation in Vanin-1 (VNN1) promoter compared to the group with poor response, in addition VNN1 mRNA expression was higher among good responders. VNN1 appears to have an important role in corticosteroid responsiveness among asthmatics, and can be used as a biomarker for treatment response $(209,210)$. Acetylation of histones by HATs activity was reported to be reduced in asthmatics treated with inhaled steroids (211). Variations in serum IgE concentrations can be influenced by DNA methylation patterns. An association between total serum IgE concentration and low methylation at 36 loci has been demonstrated, this observation may be useful in optimizing therapies with anti-IgE antibodies such as omalizumab (212).

Studies evaluating the effectiveness of peanut oral immunotherapy found a great suppressive function of Treg cells and higher levels of FOXP3 hypomethylation among treated individuals (213). In addition, a study involving cow's milk allergy children and dietary intervention using probiotic Lactobacillus rhamnosus (abundant in butyrate-producer bacteria strains) demonstrated that oral tolerance in children with IgE-mediated CMA involves epigenetic regulation of the FOXP3 gene. Difference in the methylation status of FOXP3 was found among children who developed oral tolerance after probiotic therapy (205). Prenatal administration of Acinetobacter lwoffii F78 in murine demonstrated a modulation in Th1/Th2 balance genes, with protection for asthma in the progeny, accompanied by changes in DNA acetylation (199).

Although some studies using probiotic supplementation in animal models have indicated a protective effect of probiotics on asthma and allergic Rhinitis (214,215), studies in humans are still limited due to couple limitations such as the duration of supplementation.

Many efforts have been focused on understanding and developing microbial therapies using technological approaches involving parasitology, genomics, transcriptomics, and proteomics methods. Currently with the help of bioinformatics and helminth genome sequencing initiatives it is possible through in silico analyzes to identify molecules with potential immunomodulatory properties. These databases are available on WormBase Parasite, HelmDB, and Heminth.net (216-218).

The identification of genomic sequences of helminth parasites known to down-modulate the immune system of mammalian hosts such as Ascaris suum, Necator americanus, Schistosoma mansoni, Strongyloides spp. as mentioned in previous topics in this review, have motivated the development of recombinant helminth proteins with therapeutic potential for immunemediated diseases such as protease inhibitors, cytokine homologs and lectins (219). High immunogenicity has been observed for these therapeutic recombinant proteins (220) which may be able to mimic the immunomodulation observed in helminth infections. However, standardized studies in humans as well as adequacy of doses and treatment duration are still necessary.

Epigenetic mechanisms play an important role in the regulation of immune response and are strongly influenced by microbial exposures and drug use, advancing the knowledge about such interactions may be used to both development of future target therapeutic strategies for asthma and allergies but also to discover new biological properties in current drugs in use.

The genetic susceptibility to allergic disorders is known be polygenic and recent studies have established that the presence of the gut microbiota is essential for normal gene expression $(221,222)$. The presence of certain bacterial species in the gut, such as Helicobacter pylori increases the $\mathrm{CpG}$ methylation in the promoter region of O6-methylguanine DNA methyltransferase, which ends up decreasing the expression of this DNA methyltransferase in gastric mucosa cells (222).

Lactobacilli and Bifidobacteria are the major source of butyrate and the absence of these species is important. By inhibiting HDACs, butyrate suppresses nuclear NF- $\mathrm{KB}$ activation, upregulates PPARr expression, and decreases IFNy production in the residing gut immune cells, promoting an anti-inflammatory gut environment (222). In a study with patients with allergic rhinitis, blocking the HDAC activity restored the integrity of the nasal epithelium and restored mucosal function and prevented the development of airway inflammation and hyperresponsiveness in experimental models (223).

Studies in dietary manipulation have demonstrated that diets high in methyl-donating nutrients are associated with hypermethylation of the epigenome, impacting the gene expression, especially during early development when the epigenome is first established, and can have long-term effects in adult life $(224,225)$. According to Bae et al. (225), in humans, methyl donors for DNA methylation are mostly derived from dietary methyl groups nutrients such as folate, vitamin B12, and choline. Methyl donors affect DNA methylation and immune responses such as Th17, Th1/Th2 balance, and Treg generation (225).

Additional studies are needed to better characterize the mechanisms underlying the different asthma phenotypes and their correlation with clinical characteristics, and those that contemplate the complex interaction of different epigenetic 
mechanisms and those that focus on a single-cell type or investigations at the single cell level (221, 226). In this sense, EWAS can be useful to identify patterns of epigenetic signatures among asthma and allergy phenotypes and clinical characteristics, which reinforces the potential of epigenetic changes as future biomarkers for diagnosis and target personalized therapies.

\section{AUTHOR CONTRIBUTIONS}

BF, HF, PM, CM, TS, and CF have contributed for the first draft. HF designed the figure. CF designed the work. All authors listed co-authored and proofread the manuscript and approved the final manuscript.

\section{REFERENCES}

1. Alashkar Alhamwe B, Alhamdan F, Ruhl A, Potaczek DP, Renz H. The role of epigenetics in allergy and asthma development. Curr Opin Allergy Clin Immunol. (2019) 20:48-55. doi: 10.1097/ACI.0000000000000598

2. Gibson GJ, Loddenkemper R, Lundbäck B, Sibille Y. Respiratory health and disease in Europe: the new European lung white book. Eur Respir J. (2013) 42:559-63. doi: 10.1183/09031936.00105513

3. Iqbal S, Oraka E, Chew GL, Flanders WD. Association between birthplace and current asthma: the role of environment and acculturation. Am J Public Health. (2014) 104:175-82. doi: 10.2105/AJPH.2013.301509

4. Barreto ML, Ribeiro-Silva RC, Malta DC, Oliveira-Campos M, Andreazzi MA, Cruz AA. Prevalência de sintomas de asma entre escolares do Brasil: Pesquisa Nacional em Saúde do Escolar (PeNSE 2012). Rev Bras Epidemiol. (2014) 17:106-15. doi: 10.1590/1809-4503201400050009

5. Cruz ÁA, Stelmach R, Ponte EV. Asthma prevalence and severity in lowresource communities. Curr Opin Allergy Clin Immunol. (2017) 17:18893. doi: 10.1097/ACI.0000000000000360

6. World Health Organization. Chronic Respiratory Diseases: Asthma. (2020). Available online at: https://www.who.int/news-room/q-a-detail/asthma (accessed September 30, 2020).

7. Venter C, Pereira B, Grundy J, Clayton CB, Roberts G, Higgins B, et al. Incidence of parentally reported and clinically diagnosed food hypersensitivity in the first year of life. J Allergy Clin Immunol. (2006) 117:1118-24. doi: 10.1016/j.jaci.2005.12.1352

8. Mcbride D, Keil T, Grabenhenrich L, Dubakiene R, Drasutiene G, Fiocchi A, et al. The EuroPrevall birth cohort study on food allergy: Baseline characteristics of 12,000 newborns and their families from nine European countries. Pediatr Allergy Immunol. (2012) 23:2309. doi: 10.1111/j.1399-3038.2011.01254.x

9. Basera W, Botha M, Gray CL, Lunjani N, Watkins ASM, Venter C, et al. The South African food sensitisation and food allergy population-based study of IgE-mediated food allergy: validity, safety, and acceptability. Ann Allergy Asthma Immunol. (2015) 115:113-9. doi: 10.1016/j.anai.2015.06.003

10. Tozzi AE, Armenio L, Bernardini R, Boner A, Calvani M, Cardinale F, et al. Pediatric allergy and immunology in Italy. Pediatr Allergy Immunol. (2011) 22:267-76. doi: 10.1111/j.1399-3038.2011.01157.x

11. Loh W, Tang MLK. The epidemiology of food allergy in the global context. Int J Environ Res Public Health. (2018) 15:20143. doi: 10.3390/ijerph15092043

12. Riedler J, Braun-Fahrländer C, Eder W, Schreuer M, Waser M, Maisch $\mathrm{S}$, et al. Exposure to farming in early life and development of asthma and allergy: a cross-sectional survey. Lancet. (2001) 358:112933. doi: 10.1016/S0140-6736(01)06252-3

13. Da Cunha SS, Barreto ML, Fiaccone RL, Cooper PJ, Alcantara-Neves NM, De Magalhães Simões S, et al. Asthma cases in childhood attributed to atopy in tropical area in Brazil. Rev Panam Salud Publica/Pan Am J Public Heal. (2010) 28:405-11. doi: 10.1590/S1020-49892010001200001

\section{FUNDING}

BF was supported by a Fundação de Amparo à Pesquisa do Estado da Bahia (FAPESB) (BOL0281/2020) scholarship as well as HF who was supported by Conselho Nacional de Desenvolvimento Científico e Tecnológico (CNPq) (141415/2017-7) scholarship.

\section{ACKNOWLEDGMENTS}

The authors wish to thank Coordenação de Aperfeiçoamento de Pessoal de Nível Superior (CAPES) for the support to the Immunology Graduation Program from Universidade Federal da Bahia, Brazil.

14. Barreto ML, Cunha SS, Alcântara-neves N, Carvalho LP, Cruz ÁA, Stein RT, et al. Risk factors and immunological pathways for asthma and other allergic diseases in children : background and methodology of a longitudinal study in a large urban center in Northeastern Brazil (Salvador-SCAALA study). BMC Pulm Med. (2006) 6:15. doi: 10.1186/1471-2466-6-15

15. Cruz AA, Cooper PJ, Figueiredo CA, Alcantara-Neves NM, Rodrigues LC, Barreto ML. Global issues in allergy and immunology: parasitic infections and allergy. J Allergy Clin Immunol. (2017) 140:1217-28. doi: 10.1016/j.jaci.2017.09.005

16. Umetsu DT, DeKruyff RH. The regulation of allergy and asthma. Immunol Rev. (2006) 212:238-55. doi: 10.1111/j.0105-2896.2006.00413.x

17. Siroux V, Bouzigon E. Asthma heterogeneity: the increasing genetic evidence. Lancet Respir Med. (2019) 7:469-71. doi: 10.1016/S2213-2600(19)30047-5

18. Siroux V, González JR, Bouzigon E, Curjuric I, Boudier A, Imboden M, et al. Genetic heterogeneity of asthma phenotypes identified by a clustering approach. Eur Respir J. (2014) 43:439-52. doi: 10.1183/09031936.000 32713

19. Weiss ST, Raby BA. Asthma genetics 2003. Hum Mol Genet. (2004) 13:839. doi: 10.1093/hmg/ddh080

20. Clayton D, McKeigue PM. Epidemiological methods for studying genes and environmental factors in complex diseases. Lancet. (2001) 358:135660. doi: 10.1016/S0140-6736(01)06418-2

21. Cooper RS. Gene-Environment interactions and the etiology of common complex disease. Ann Intern Med. (2003) 139:43740. doi: 10.7326/0003-4819-139-5_Part_2-200309021-00011

22. Strachan D. P. Family site, infection and atopy: the first decade of the "hygiene hypothesis". Thorax. (2000) 55:210. doi: 10.1136/thorax.55.suppl_1.S2

23. Gaviola C, Miele $\mathrm{CH}$, Wise RA, Gilman RH, Jaganath D, Miranda JJ, et al. Urbanisation but not biomass fuel smoke exposure is associated with asthma prevalence in four resource-limited settings. Thorax. (2016) 71:154-60. doi: 10.1136/thoraxjnl-2015-207584

24. Strachan DP. Hay fever, hygiene, and household size. $\mathrm{Br}$ Med J. (1989) 299:1259-60. doi: 10.1136/bmj.299.6710.1259

25. de Andrade CM, Carneiro VL, Cerqueira JV, Fonseca HF, Queiroz GA, Costa RS, et al. Parasites and allergy: observations from Brazil. Parasite Immunol. (2019) 41:1-9. doi: 10.1111/pim.12588

26. Rook GAW, Lowry CA, Raison CL. Microbial "Old Friends", immunoregulation and stress resilience. Evol Med Public Heal. (2013) 2013:46-64. doi: 10.1093/emph/eot004

27. Von Hertzen L, Laatikainen T, Pitkänen T, Vlasoff T, Mäkelä MJ, Vartiainen E, et al. Microbial content of drinking water in Finnish and Russian Karelia Implications for atopy prevalence. Allergy Eur J Allergy Clin Immunol. (2007) 62:288-92. doi: 10.1111/j.1398-9995.2006.01281.x

28. Haahtela T. A biodiversity hypothesis. Allergy Eur J Allergy Clin Immunol. (2019) 74:1445-56. doi: 10.1111/all.13763

29. Hanski I, Von Hertzen L, Fyhrquist N, Koskinen K, Torppa K, Laatikainen $\mathrm{T}$, et al. Environmental biodiversity, human microbiota, 
and allergy are interrelated. Proc Natl Acad Sci USA. (2012) 109:83349. doi: 10.1073/pnas. 1205624109

30. McKeever TM, Lewis SA, Smith C, Collins J, Heatlie H, Frischer M, et al. Early exposure to infections and antibiotics and the incidence of allergic disease: a birth cohort study with the West Midlands general practice research database. I Allergy Clin Immunol. (2002) 109:4350. doi: $10.1067 /$ mai.2002.121016

31. Van Den Biggelaar AMJ, Rodrigues LC, Van Ree R, Van Der Zee JS, Hoeksma-Kruize YCM, Souverijn JHM, et al. Long-term treatment of intestinal helminths increases mite skin-test reactivity in Gabonese schoolchildren. J Infect Dis. (2004) 189:892-900. doi: 10.1086/381767

32. Smits HH, Hammad H, van Nimwegen M, Soullie T, Willart MA, Lievers E, et al. Protective effect of Schistosoma mansoni infection on allergic airway inflammation depends on the intensity and chronicity of infection. J Allergy Clin Immunol. (2007) 120:932-40. doi: 10.1016/j.jaci.2007.06.009

33. Cooper PJ. Interactions between helminth parasites and allergy. Curr Opin Allergy Clin Immunol. (2009) 9:29-37. doi: 10.1097/ACI.0b013e32831f44a6

34. Medeiros M, Figueiredo JP, Almeida MC, Matos MA, Araújo MI, Cruz AA, et al. Schistosoma mansoni infection is associated with a reduced course of asthma. J Allergy Clin Immunol. (2003) 111:94751. doi: 10.1067/mai.2003.1381

35. Gonçales JP, Nobrega CGO, Nascimento WRC, Lorena VMB, Peixoto DM, Costa VMA, et al. Cytokine production in allergic and Trichuris trichiurainfected children from an urban region of the Brazilian northeast. Parasitol Int. (2020) 74:101918. doi: 10.1016/j.parint.2019.04.015

36. Alcântara-Neves NM, Badaró SJ, dos Santos MCA, Pontes-de-Carvalho L, Barreto ML. The presence of serum anti-Ascaris lumbricoides IgE antibodies and of Trichuris trichiura infection are risk factors for wheezing and/or atopy in preschool-aged Brazilian children. Respir Res. (2010) 11:19. doi: 10.1186/1465-9921-11-114

37. Vest KG. Zika virus: a basic overview of an emerging arboviral infection in the Western Hemisphere. Disaster Med Public Health Prep. (2016) 10:70712. doi: $10.1017 / \mathrm{dmp} .2016 .43$

38. Lorenz C, Azevedo TS, Virginio F, Aguiar BS, Chiaravalloti-Neto F, Suesdek L. Impact of environmental factors on neglected emerging arboviral diseases. PLoS Negl Trop Dis. (2017) 11:1-19. doi: 10.1371/journal.pntd.0005959

39. Rodriguez-Morales AJ, Ortiz-Martínez Y, Patiño-Barbosa AM. Yellow fever in the Americas: The growing concern about new epidemics. F1000Res. (2017) 6:1-12. doi: 10.12688/f1000research.11280.2

40. Strunz EC, Addiss DG, Stocks ME, Ogden S, Freeman MC, Parasitologi D, et al. Associations between selective attention and soil-transmitted helminth infections, socioeconomic status, and physical fitness in disadvantaged children in Port Elizabeth, South Africa: An observational study. PLoS Negl Trop Dis. (2017) 8:1-9. doi: 10.1371/journal.pntd.0005573

41. Babamale OA, Ugbomoiko US, Heukelbach J. High prevalence of Plasmodium falciparum and soil-transmitted helminth co-infections in a periurban community in Kwara State, Nigeria. J Infect Public Health. (2018) 11:48-53. doi: 10.1016/j.jiph.2017.03.002

42. Cooper PJ, Chico ME, Vaca MG, Sandoval CA, Loor S, Amorim L, et al. Effect of early life geohelminth infections on the development of wheezing at 5 years of age. Am J Respir Crit Care Med. (2017) 197:36472. doi: $10.1164 / \mathrm{rccm} .201706-1222 \mathrm{OC}$

43. Acevedo N, Caraballo L. IgE cross-reactivity between Ascaris lumbricoides and mite allergens: possible influences on allergic sensitization and asthma. Parasite Immunol. (2011) 33:309-21. doi: 10.1111/j.1365-3024.2011. 01288.x

44. Sánchez-Borges M, Capriles-Hulett A, Torres J, Ansotegui-Zubeldia IJ, Castillo A, Dhersy A, et al. Diagnosis of allergic sensitization in patients with allergic rhinitis and asthma in a tropical environment. Rev Alerg Mex. (2019) 66:44-54. doi: 10.29262/ram.v66i1.570

45. Jeevarathnum AC, van Niekerk A, Green RJ, Becker P, Masekela R. Prevalence of Blomia tropicalis allergy in two regions of South Africa. South African Med J. (2015) 105:567-9. doi: 10.7196/SAMJnew.7786

46. Marsit CJ. Influence of environmental exposure on human epigenetic regulation. J Exp Biol. (2015) 218:71-9. doi: 10.1242/jeb.106971

47. Logan AC, Jacka FN, Prescott SL. Immune-microbiota interactions: dysbiosis as a global health issue. Curr Allergy Asthma Rep. (2016) 16:19. doi: 10.1007/s11882-015-0590-5
48. Cavalier-Smith T. Symbiosis as a source of evolutionary innovation: Speciation and morphogenesis. Trends Ecol Evol. (1992) 7:422-3. doi: 10.1016/0169-5347(92)90028-A

49. Simon JC, Marchesi JR, Mougel C, Selosse MA. Host-microbiota interactions: from holobiont theory to analysis. Microbiome. (2019) 7:15. doi: 10.1186/s40168-019-0619-4

50. Berg G, Rybakova D, Fischer D, Cernava T, Vergès MCC, Charles $\mathrm{T}$, et al. Microbiome definition re-visited: old concepts and new challenges. Microbiome. (2020) 8:103. doi: 10.1186/s40168-020-0 0875-0

51. Bordenstein SR, Theis KR. Host biology in light of the microbiome: ten principles of holobionts and hologenomes. PLoS Biol. (2015) 13:123. doi: 10.1371/journal.pbio.1002226

52. Foster KR, Schluter J, Coyte KZ, Rakoff-Nahoum S. The evolution of the host microbiome as an ecosystem on a leash. Nature. (2017) 548:4351. doi: 10.1038 /nature23292

53. Zilber-Rosenberg I, Rosenberg E. Role of microorganisms in the evolution of animals and plants: the hologenome theory of evolution. FEMS Microbiol Rev. (2008) 32:723-35. doi: 10.1111/j.1574-6976.2008.00123.x

54. Mills JG, Brookes JD, Gellie NJC, Liddicoat C, Lowe AJ, Sydnor HR, et al. Relating urban biodiversity to human health with the "Holobiont" concept. Front Microbiol. (2019) 10:550. doi: 10.3389/fmicb.2019.00550

55. Garcia GD, Gregoracci GB, de Santos OE, Meirelles PM, Silva GGZ, Edwards R, et al. Metagenomic analysis of healthy and white plagueaffected mussismilia braziliensis corals. Microb Ecol. (2013) 65:107686. doi: 10.1007/s00248-012-0161-4

56. Azad MB, Kozyrskyj AL. Perinatal programming of asthma: the role of gut microbiota. Clin Dev Immunol. (2012) 2012:932072. doi: 10.1155/2012/932072

57. American Veterinary Medical Association. One health: a new professional imperative. One Heal Initiat Task Force Final Rep. (2008). Available online at: https://www.avma.org/KB/Resources/Reports/Documents/onehealth_ final.pdf (accessed September 30, 2020).

58. Mascarenhas R, Ruziska FM, Moreira EF, Campos AB, Loiola M, Reis K, et al. Integrating computational methods to investigate the macroecology of microbiomes. Front Genet. (2020) 10:1344. doi: 10.3389/fgene.2019.01344

59. Kamada N, Seo SU, Chen GY, Núñez G. Role of the gut microbiota in immunity and inflammatory disease. Nat Rev Immunol. (2013) 13:32135. doi: $10.1038 /$ nri3430

60. Kogut MH, Lee A, Santin E. Microbiome and pathogen interaction with the immune system. Poult Sci. (2020) 99:1906-13. doi: 10.1016/j.psj.2019.12.011

61. Kabat AM, Pott J, Maloy KJ. The mucosal immune system and its regulation by autophagy. Front Immunol. (2016) 7:1-25. doi: 10.3389/fimmu.2016.00240

62. D'Amelio P, Sassi F. Gut microbiota, immune system, and bone. Calcif Tissue Int. (2018) 102:415-25. doi: 10.1007/s00223-017-0331-y

63. Pontes-de-Carvalho L, Mengel J, Figueiredo CA, and Alcântara-Neves NM. Antigen mimicry between infectious agents and self or environmental antigens may lead to long-term regulation of inflammation. Front Immunol. (2013) 4:1-5. doi: 10.3389/fimmu.2013.00314

64. Shi $\mathrm{N}$, Li $\mathrm{N}$, Duan $\mathrm{X}$, Niu $\mathrm{H}$. Interaction between the gut microbiome and mucosal immune system. Mil Med Res. (2017) 4:1-7. doi: 10.1186/s40779-017-0122-9

65. Yi M, Yu S, Qin S, Liu Q, Xu H, Zhao W, et al. Gut microbiome modulates efficacy of immune checkpoint inhibitors. J Hematol Oncol. (2018) 11:110. doi: 10.1186/s13045-018-0592-6

66. Chen P. Gut Microbiota Pathogenesis of Organ Injury. Springer (2020). doi: 10.1007/978-981-15-2385-4

67. Yamashiro Y. Gut microbiota in health and disease. Ann Nutr Metab. (2018) 71:242-6. doi: 10.1159/000481627

68. Lee GR. The balance of th17 versus treg cells in autoimmunity. Int J Mol Sci. (2018) 19:1-14. doi: 10.3390/ijms19030730

69. Tanoue T, Atarashi K, Honda K. Development and maintenance of intestinal regulatory $\mathrm{T}$ cells. Nat Rev Immunol. (2016) 16:295-309. doi: 10.1038/nri.2016.36

70. Hirota K, Turner J, Villa M, Duarte JH, Demengeot J. Th17 cell plasticity in Peyer's patches is responsible for induction of T cell-dependent IgA responses. Nat Immunol. (2013) 14:372-9. doi: 10.1038/ni.2552 
71. Pabst O, Slack E. IgA and the intestinal microbiota: the importance of being specific. Mucosal Immunol. (2020) 13:1221. doi: 10.1038/s41385-019-0227-4

72. Constantinides MG. Interactions between the microbiota and innate and innate-like lymphocytes. J Leukoc Biol. (2018) 103:409-19. doi: 10.1002/JLB.3RI0917-378R

73. Kanamori M, Nakatsukasa H, Okada M, Lu Q, Yoshimura A. Induced regulatory $\mathrm{T}$ cells: their development, stability, and applications. Trends Immunol. (2016) 37:803-11. doi: 10.1016/j.it.2016.08.012

74. Cheng H, Guan X, Chen D, Ma W. The Th17/Treg cell balance: a gut microbiota-modulated story. Microorganisms. (2019) 7:583. doi: $10.3390 /$ microorganisms 7120583

75. Thursby E, Juge N. Introduction to the human gut microbiota. Biochem J. (2017) 474:1823-36. doi: 10.1042/BCJ20160510

76. Sun M, Wu W, Liu Z, Cong Y. Microbiota metabolite short chain fatty acids, GPCR, and inflammatory bowel diseases. J Gastroenterol. (2017) 52:1-8. doi: 10.1007/s00535-016-1242-9

77. McKenzie C, Tan J, Macia L, Mackay CR. The nutrition-gut microbiomephysiology axis and allergic diseases. Immunol Rev. (2017) 278:27795. doi: 10.1111/imr.12556

78. Theiler A, Bärnthaler T, Platzer W, Richtig G, Peinhaupt $\mathrm{M}$, Rittchen $\mathrm{S}$, et al. Butyrate ameliorates allergic airway inflammation by limiting eosinophil trafficking and survival. $J$ Allergy Clin Immunol. (2019) 144:764-76. doi: 10.1016/j.jaci.2019. 05.002

79. Thio CLP, Chi PY, Lai ACY, Chang YJ. Regulation of type 2 innate lymphoid cell-dependent airway hyperreactivity by butyrate. J Allergy Clin Immunol. (2018) 142:1867-83.e12. doi: 10.1016/j.jaci.2018. 02.032

80. Usami M, Kishimoto K, Ohata A, Miyoshi M, Aoyama M, Fueda Y, et al. Butyrate and trichostatin $\mathrm{A}$ attenuate nuclear factor $\kappa \mathrm{B}$ activation and tumor necrosis factor $\alpha$ secretion and increase prostaglandin E2 secretion in human peripheral blood mononuclear cells. Nutr Res. (2008) 28:3218. doi: 10.1016/j.nutres.2008.02.012

81. Vinolo MAR, Rodrigues HG, Hatanaka E, Sato FT, Sampaio SC, Curi R. Suppressive effect of short-chain fatty acids on production of proinflammatory mediators by neutrophils. J Nutr Biochem. (2011) 22:84955. doi: 10.1016/j.jnutbio.2010.07.009

82. Naglik JR, König A, Hube B, Gaffen SL. Candida albicans-epithelial interactions and induction of mucosal innate immunity. Curr Opin Microbiol. (2017) 40:104-12. doi: 10.1016/j.mib.2017.10.030

83. Budden KF, Shukla SD, Rehman SF, Bowerman KL, Keely S, Hugenholtz $\mathrm{P}$, et al. Functional effects of the microbiota in chronic respiratory disease. Lancet Respir. (2019) 2600:1-14. doi: 10.1016/S2213-2600(18)30510-1

84. Seo SU, Kweon MN. Virome-host interactions in intestinal health and disease. Curr Opin Virol. (2019) 37:63-71. doi: 10.1016/j.coviro.2019.06.003

85. Van der Kleij D, Latz E, Brouwers JFHM, Kruize YCM, Schmitz M, Kurt-Jones EA, et al. A novel host-parasite lipid cross-talk. Schistosomal lyso-phosphatidylserine activates toll-like receptor 2 and affects immune polarization. J Biol Chem. (2002) 277:48122-9. doi: 10.1074/jbc.M206941200

86. Magalhães KG, Almeida PE, Atella GC, Maya-Monteiro CM, CastroFaria-Neto HC, Pelajo-Machado $M$, et al. Schistosomal-derived lysophosphatidylcholine are involved in eosinophil activation and recruitment through toll-like receptor-2-dependent mechanisms. J Infect Dis. (2010) 202:1369-79. doi: 10.1086/656477

87. Iwami D, Nonomura K, Shirasugi N, Niimi M. Immunomodulatory effects of eicosapentaenoic acid through induction of regulatory $\mathrm{T}$ cells. Int Immunopharmacol. (2011) 11:384-9. doi: 10.1016/j.intimp.2010.11.035

88. Thomas PG, Carter MR, Atochina O, Da'Dara AA, Piskorska D, McGuire E, et al. Maturation of dendritic cell 2 phenotype by a helminth glycan uses a toll-like receptor 4-dependent mechanism. J Immunol. (2003) 171:583741. doi: 10.4049/jimmunol.171.11.5837

89. Durães FV, Carvalho NB, Melo TT, Oliveira SC, Fonseca CT. IL-12 and TNF- $\alpha$ production by dendritic cells stimulated with Schistosoma mansoni schistosomula tegument is TLR4- and MyD88-dependent. Immunol Lett. (2009) 125:72-7. doi: 10.1016/j.imlet.2009.06.004

90. Cardoso LS, Oliveira SC, Góes AM, Oliveira RR, Pacífico LG, Marinho $\mathrm{FV}$, et al. Schistosoma mansoni antigens modulate the allergic response in a murine model of ovalbumin-induced airway inflammation. Clin Exp Immunol. (2010) 160:266-74. doi: 10.1111/j.1365-2249.2009.04084.x

91. van Riet E, Everts B, Retra K, Phylipsen M, van Hellemond JJ, Tielens AGM, et al. Combined TLR2 and TLR4 ligation in the context of bacterial or helminth extracts in human monocyte derived dendritic cells: Molecular correlates for Th1/Th2 polarization. BMC Immunol. (2009) 10:112. doi: 10.1186/1471-2172-10-9

92. Auriault C, Gras-Masse H, Pierce RJ, Butterworth AE, Wolowczuk I, Capron $\mathrm{M}$, et al. Antibody response of Schistosoma mansoni-infected human subjects to the recombinant P28 glutathione-S-transferase and to synthetic peptides. J Clin Microbiol. (1990) 28:1918-24. doi: 10.1128/JCM.28.9.1918-1924.1990

93. Gazzinelli RT, Denkers EY. Protozoan encounters with toll-like receptor signalling pathways: implications for host parasitism. Nat Rev Immunol. (2006) 6:895-906. doi: 10.1038/nri1978

94. Horinouchi S, Ueda K, Nakayama J, Ikeda T. Cell-to-cell communications among microorganisms. Compr Nat Prod II Chem Biol. (2010) 4:283337. doi: 10.1016/B978-008045382-8.00098-8

95. Kim $\mathrm{CH}$. Immune regulation by microbiome metabolites. Immunology. (2018) 154:220-9. doi: 10.1111/imm.12930

96. Mu Q, Tavella VJ, Luo XM. Role of Lactobacillus reuteri in human health and diseases. Front Microbiol. (2018) 9:1-17. doi: 10.3389/fmicb.2018. 00757

97. Paterson MJ, Oh S, Underhill DM. Host-microbe interactions: commensal fungi in the gut. Curr Opin Microbiol. (2017) 40:131-7. doi: 10.1016/j.mib.2017.11.012

98. Tong Y, Tang J. Candida albicans infection and intestinal immunity. Microbiol Res. (2017) 198:27-35. doi: 10.1016/j.micres.2017.02.002

99. Spikes S, Xu R, Nguyen CK, Chamilos G, Kontoyiannis DP, Jacobson $\mathrm{RH}$, et al. Gliotoxin production in Aspergillus fumigatus contributes to host-specific differences in virulence. J Infect Dis. (2008) 197:47986. doi: $10.1086 / 525044$

100. Tan Y, Wu X, Sun J, Guo W, Gong F, Shao F, et al. A fumigaclavine C isostere alleviates Th1-mediated experimental colitis via competing with IFN- $\gamma$ for binding to IFN- $\gamma$ receptor 1. Biochem Pharmacol. (2017) 123:6372. doi: 10.1016/j.bcp.2016.10.004

101. Li YX, Himaya SWA, Dewapriya P, Zhang C, Kim SK. Fumigaclavine C from a marine-derived fungus Aspergillus fumigatus induces apoptosis in MCF-7 breast cancer cells. Mar Drugs. (2013) 11:5063-86. doi: 10.3390/md11125063

102. Mukhopadhya I, Segal JP, Carding SR, Hart AL, Hold GL. The gut virome : the 'missing link' between gut bacteria and host immunity? (2019) 12:1756284819836620. doi: 10.1177/1756284819836620

103. Shamri R, Xenakis JJ, Spencer LA. Eosinophils in innate immunity: an evolving story. Cell Tissue Res. (2013) 343:5783. doi: 10.1007/s00441-010-1049-6

104. Falcão PL, Correa-Oliveira R, Fraga LAO, Talvani A, Proudfoot AEI, Wells TNC, et al. Plasma concentrations and role of macrophage inflammatory protein-1 $\alpha$ during chronic Schistosoma mansoni infection in humans. J Infect Dis. (2002) 186:1696-700. doi: 10.1086/345370

105. Souza ALS, Sousa-Pereira SR, Teixeira MM, Lambertucci JR, Teixeira AL. The role of chemokines in Schistosoma mansoni infection: insights from human disease and murine models. Mem Inst Oswaldo Cruz. (2006) 101:3338. doi: 10.1590/S0074-02762006000900054

106. Acevedo N, Mohr J, Zakzuk J, Samonig M, Briza P, Erler A, et al. Proteomic and immunochemical characterization of glutathione transferase as a new allergen of the nematode Ascaris lumbricoides. PLoS ONE. (2013) 8:e78353. doi: 10.1371/journal.pone.0078353

107. Gaze S, McSorley HJ, Daveson J, Jones D, Bethony JM, Oliveira LM, et al. Characterising the mucosal and systemic immune responses to experimental human hookworm infection. PLoS Pathog. (2012) 8:e1002520. doi: 10.1371/journal.ppat.1002520

108. Croese J, Giacomin P, Navarro S, Clouston A, McCann L, Dougall A, et al. Experimental hookworm infection and gluten microchallenge promote tolerance in celiac disease. J Allergy Clin Immunol. (2015) 135:50816.e5. doi: 10.1016/j.jaci.2014.07.022

109. McSorley HJ, Gaze S, Daveson J, Jones D, Anderson RP, Clouston A, et al. Suppression of inflammatory immune responses in celiac disease by experimental hookworm infection. PLoS ONE. (2011) 6:e24092. doi: 10.1371/journal.pone.0024092 
110. Hartgers FC, Obeng BB, Kruize YCM, Dijkhuis A, McCall M, Sauerwein RW, et al. Responses to malarial antigens are altered in helminth-infected children. J Infect Dis. (2009) 199:1528-35. doi: 10.1086/598687

111. Renz H, Adkins BD, Bartfeld S, Blumberg RS, Farber DL, Garssen J, et al. The neonatal window of opportunity-early priming for life. J Allergy Clin Immunol. (2018) 141:1212-4. doi: 10.1016/j.jaci.2017.11.019

112. Ver Heul A, Planer J, Kau AL. The human microbiota and asthma. Clin Rev Allergy Immunol. (2019) 57:350-63. doi: 10.1007/s12016-018-8719-7

113. Von Mutius E. Environmental factors influencing the development and progression of pediatric asthma. J Allergy Clin Immunol. (2002) 109:S52532. doi: $10.1067 /$ mai.2002.124565

114. Zenclussen AC, Fest S, Busse P, Joachim R, Klapp BF, Arck PC. Questioning the Th1/Th2 paradigm in reproduction: peripheral levels of IL-12 are down-regulated in miscarriage patients. Am J Reprod Immunol. (2002) 48:245-51. doi: 10.1034/j.1600-0897.2002.0 1136.x

115. Gorczynski RM, Hadidi S, Yu G, Clark DA. The same immunoregulatory molecules contribute to successful pregnancy and transplantation. Am J Reprod Immunol. (2002) 48:18-26. doi: 10.1034/j.1600-0897.2002.0 1094.x

116. Wegmann TG, Lin H, Guilbert L, Mosmann TR. Bidirectional cytokine interactions in the maternal-fetal relationship: is successful pregnancy a TH2 phenomenon? Immunol Today. (1993) 14:353-6. doi: 10.1016/0167-5699(93)90235-D

117. Chang TW. Changing patterns of antigen exposure and their impact on the prevalence of allergy. Pediatr Allergy Immunol. (2014) 25:7339. doi: 10.1111/pai.12297

118. Stensballe LG, Simonsen J, Jensen SM, Bønnelykke K, Bisgaard H. Use of antibiotics during pregnancy increases the risk of asthma in early childhood. J Pediatr. (2013) 162:832-8.e3. doi: 10.1016/j.jpeds.2012.09.049

119. Gollwitzer ES, Saglani S, Trompette A, Yadava K, Sherburn R, McCoy KD, et al. Lung microbiota promotes tolerance to allergens in neonates via PD-L1. Nat Med. (2014) 20:642-7. doi: 10.1038/nm.3568

120. Huang YJ, Boushey HA. The microbiome in asthma. J Allergy Clin Immunol. (2015) 135:25-30. doi: 10.1016/j.jaci.2014.11.011

121. Marri PR, Stern DA, Wright AL, Billheimer D, Martinez FD. Asthmaassociated differences in microbial composition of induced sputum. J Allergy Clin Immunol. (2013) 131:346-52.e1-3. doi: 10.1016/j.jaci.2012.11.013

122. Vlaski E, Lawson JA. Urban-rural differences in asthma prevalence among young adolescents: the role of behavioural and environmental factors. Allergol Immunopathol. (2015) 43:131-41. doi: 10.1016/j.aller.2013.09.016

123. von Mutius E, Braun-Fahrländer C, Schierl R, Riedler J, Ehlermann S, Maisch S, et al. Exposure to endotoxin or other bacterial components might protect against the development of atopy. Clin Exp Allergy. (2000) 30:1230-4. doi: 10.1046/j.1365-2222.2000.00959.x

124. Leonardi-Bee J, Pritchard D, Britton J. Asthma and current intestinal parasite infection: systematic review and meta-analysis. Am J Respir Crit Care Med. (2006) 174:514-23. doi: 10.1164/rccm.200603-331OC

125. Maizels RM, Yazdanbakhsh M. Immune regulation by helminth parasites: cellular and molecular mechanisms. Nat Rev Immunol. (2003) 3:73344. doi: $10.1038 /$ nri1183

126. Pulendran B, Artis D. New paradigms in type 2 immunity. Science. (2012) 337:431-5. doi: 10.1126/science.1221064

127. Dagoye D, Bekele Z, Woldemichael K, Nida H, Yimam M, Hall A, et al. Wheezing, allergy, and parasite infection in children in urban and rural ethiopia. Am J Respir Crit Care Med. (2003) 167:1369-73. doi: 10.1164/rccm.200210-1204OC

128. Amedei A, Codolo G, Del Prete G, de Bernard M, D’Elios MM. The effect of Helicobacter pylori on asthma and allergy. J Asthma Allergy. (2010) 3:139-47. doi: 10.2147/JAA.S8971

129. von Moltke J, Ji M, Liang H-E, Locksley RM. Tuft-cell-derived IL-25 regulates an intestinal ILC2-epithelial response circuit. Nature. (2016) 529:221-5. doi: 10.1038/nature16161

130. Scrivener S, Yemaneberhan H, Zebenigus M, Tilahun D, Girma S, Ali S, et al. Independent effects of intestinal parasite infection and domestic allergen exposure on risk of wheeze in Ethiopia: a nested case-control study. Lancet. (2001) 358:1493-9. doi: 10.1016/S0140-6736(01)06579-5
131. Lieberman LA, Hunter CA. The role of cytokines and their signaling pathways in the regulation of immunity to Toxoplasma gondii. Int Rev Immunol. (2002) 21:373-403. doi: 10.1080/08830180213281

132. Aliberti J. Host persistence: exploitation of anti-inflammatory pathways by Toxoplasma gondii. Nat Rev Immunol. (2005) 5:162-70. doi: 10.1038/nri1547

133. Fenoy I, Giovannoni M, Batalla E, Martin V, Frank FM, Piazzon I, et al. Toxoplasma gondii infection blocks the development of allergic airway inflammation in BALB/c mice. Clin Exp Immunol. (2009) 155:27584. doi: 10.1111/j.1365-2249.2008.03813.x

134. Andrade MMC, Carneiro VL, Galvão AA, Fonseca TR, Vitor RWA, Alcantara-Neves NM, et al. Toxoplasma gondii protects from IgE sensitization and induces Th1/Th2 immune profile. Parasite Immunol. (2020) 42:1-7. doi: 10.1111/pim.12694

135. Mendonça LR, Veiga RV, Dattoli VCC, Figueiredo CA, Fiaccone R, Santos $\mathrm{J}$, et al. Toxocara seropositivity, atopy and wheezing in children living in poor neighbourhoods in Urban Latin American. PLoS Negl Trop Dis. (2012) 6:e0001886. doi: 10.1371/journal.pntd.0001886

136. Silva MB, Amor ALM, Santos LN, Galvão AA, Oviedo Vera AV, Silva ES, et al. Risk factors for Toxocara spp. seroprevalence and its association with atopy and asthma phenotypes in school-age children in a small town and semi-rural areas of Northeast Brazil. Acta Trop. (2017) 174:158-64. doi: 10.1016/j.actatropica.2016.04.005

137. Akay HK, Bahar Tokman H, Hatipoglu N, Hatipoglu H, Siraneci R, Demirci $\mathrm{M}$, et al. The relationship between bifidobacteria and allergic asthma and/or allergic dermatitis: a prospective study of 0-3 years-old children in Turkey. Anaerobe. (2014) 28:98-103. doi: 10.1016/j.anaerobe.2014.05.006

138. Vael C, Nelen V, Verhulst SL, Goossens H, Desager KN. Early intestinal Bacteroides fragilis colonisation and development of asthma. BMC Pulm Med. (2008) 8:1-6. doi: 10.1186/1471-2466-8-19

139. Ogawa H, Fujimura M, Ohkura N, Satoh K, Makimura K. Fungus-associated asthma: overcoming challenges in diagnosis and treatment. Expert Rev Clin Immunol. (2014) 10:647-56. doi: 10.1586/1744666X.2014.892829

140. Sharma A, Laxman B, Naureckas ET, Hogarth DK, Sperling AI, Solway $\mathrm{J}$, et al. Associations between fungal and bacterial microbiota of airways and asthma endotypes. J Allergy Clin Immunol. (2019) 144:121427.e7. doi: 10.1016/j.jaci.2019.06.025

141. Zhou X, Dang YJ, Wang GF, Jin XQ. Effects of Aspergillus fumigatus on glucocorticoid receptor and $\beta 2$-adrenergic receptor expression in a rat model of asthma. Exp Lung Res. (2017) 43:197-207. doi: 10.1080/01902148.2017.1339142

142. de Almeida TVVS, Fernandes JS, Lopes DM, Andrade LS, Oliveira SC, Carvalho EM, et al. Schistosoma mansoni antigens alter activation markers and cytokine profile in lymphocytes of patients with asthma. Acta Trop. (2017) 166:268-79. doi: 10.1016/j.actatropica.2016.12.002

143. Marinho FV, Alves CC, De Souza SC, Da Silva CMG, Cassali GD, Oliveira SC, et al. Schistosoma mansoni Tegument (Smteg) Induces IL10 and modulates experimental airway inflammation. PLOS ONE. (2016) 11:e0160118. doi: 10.1371/journal.pone.0160118

144. Cooper PJ, Chico ME, Platts-Mills TAE, Rodrigues LC, Strachan DP, Barreto ML. Cohort profile: the ecuador life (ECUAVIDA) study in esmeraldas province, ecuador. Int J Epidemiol. (2015) 44:151727. doi: $10.1093 /$ ije/dyu 128

145. Mehta RS, Rodriguez A, Chico M, Guadalupe I, Broncano N, Sandoval $\mathrm{C}$, et al. Maternal geohelminth infections are associated with an increased susceptibility to geohelminth infection in children: a case-control study. PLoS Negl Trop Dis. (2012) 6:3-8. doi: 10.1371/journal.pntd.0001753

146. Guadalupe I, Mitre E, Benitez S, Chico ME, Nutman TB, Cooper PJ. UKPMC funders group author manuscript newborns of mothers with ascariasis. Blood. (2010) 199:1846-50. doi: 10.1086/599214

147. Pitrez PM, Gualdi LP, Barbosa GL, Sudbrack S, Ponzi D, Cao RG, et al. Effect of different helminth extracts on the development of asthma in mice: the influence of early-life exposure and the role of IL-10 response. Exp Parasitol. (2015) 156:95-103. doi: 10.1016/j.exppara.2015.06.004

148. Veiga RV, Cunha SS, Dattoli VCC, Cruz ÁC, Cooper PJ, Rodrigues LC, et al. Chronic virus infections supress atopy but not asthma in a set of children from a large latin american city: a cross-section study. BMC Pulm Med. (2011) 11:24. doi: 10.1186/1471-2466-11-24 
149. Von Hertzen LC, Laatikainen T, Mäkelä MJ, Jousilahti P, Kosunen TU, Petäys $\mathrm{T}$, et al. Infectious burden as a determinant of atopy - A comparison between adults in Finnish and Russian karelia. Int Arch Allergy Immunol. (2006) 140:89-95. doi: 10.1159/000092251

150. Matricardi PM, Rosmini F, Ferrigno L, Nisini R, Rapicetta M, Chionne P, et al. Cross sectional retrospective study of prevalence of atopy among Italian military students with antibodies against hepatitis A virus. $\mathrm{Br}$ Med J. (1997) 314:1009-12. doi: 10.1136/bmj.314.7086.999

151. Gonzalez-Quintela A, Gude F, Boquete O, Aguilera A, Rey J, Meijide LM, et al. Association of hepatitis A virus infection with allergic sensitization in a population with high prevalence of hepatitis A virus exposure. Allergy Eur J Allergy Clin Immunol. (2005) 60:98103. doi: 10.1111/j.1398-9995.2005.00682.x

152. Matricardi PM, Rosmini F, Panetta V, Ferrigno L, Bonini S. Hay fever and asthma in relation to markers of infection in the United States. J Allergy Clin Immunol. (2002) 110:381-7. doi: 10.1067/mai.2002.126658

153. Kocabaş E, Yapicioglu H, Yildizdaş D, Kendirli SG, Burgut R. The prevalence of atopy in children with antibodies against hepatitis A virus and hepatitis B virus. Turk J Pediatr. (2006) 48:189-96.

154. Aaby P, Shaheen SO, Heyes CB, Goudiaby A, Hall AJ, Shiell AW, et al. Early BCG vaccination and reduction in atopy in Guinea-Bissau. Clin Exp Allergy. (2000) 30:644-50. doi: 10.1046/j.1365-2222.2000.00803.x

155. Krause TG, Hviid A, Koch A, Friborg J, Hjuler T, Wohlfahrt J, et al. BCG Vaccination and risk of atopy. J Am Med Assoc. (2003) 289:10125. doi: 10.1001/jama.289.8.1012

156. Yamamoto-Hanada K, Pak K, Saito-Abe M, Yang L, Sato M, Mezawa H, et al. Cumulative inactivated vaccine exposure and allergy development among children: a birth cohort from Japan. Environ Health Prev Med. (2020) 25:1-10. doi: 10.1186/s12199-020-00864-7

157. Stokholm J, Blaser MJ, Thorsen J, Rasmussen MA, Waage J, Vinding RK, et al. Maturation of the gut microbiome and risk of asthma in childhood. Nat Commun. (2018) 9:704. doi: 10.1038/s41467-018-03150-x

158. Abdel-Aziz MI, Vijverberg SJH, Neerincx AH, Kraneveld AD, Maitlandvan der Zee $\mathrm{AH}$. The crosstalk between microbiome and asthma: exploring associations and challenges. Clin Exp Allergy. (2019) 49:106786. doi: 10.1111/cea.13444

159. Protudjer JLP, Sevenhuysen GP, Ramsey CD, Kozyrskyj AL, Becker AB. Low vegetable intake is associated with allergic asthma and moderateto-severe airway hyperresponsiveness. Pediatr Pulmonol. (2012) 47:115969. doi: 10.1002/ppul.22576

160. Denning DW, O'Driscoll BR, Hogaboam CM, Bowyer P, Niven RM. The link between fungi and severe asthma: a summary of the evidence. Eur Respir J. (2006) 27:615-26. doi: 10.1183/09031936.06.000 74705

161. Tham R, Dharmage SC, Taylor PE, Katelaris CH, Vicendese D, Abramson MJ, et al. Outdoor fungi and child asthma health service attendances. Pediatr Allergy Immunol. (2014) 25:439-49. doi: 10.1111/pai.12257

162. Dupont C, Armant DR, Brenner CA. Epigenetics: definition, mechanisms and clinical perspective. Semin Reprod Med. (2009) 27:351-7. doi: 10.1055/s-0029-1237423

163. Waddington $\mathrm{CH}$. Canalization of development and the inheritance of acquired characters. Nat Publ Gr. (1942) 150:405-6. doi: 10.1038/15 $0563 \mathrm{a} 0$

164. Waddington $\mathrm{CH}$. Genetic assimilation of the bithorax phenotype. Int J Org Evol. (1956) 10:993-1007. doi: 10.2307/2406091

165. Waechter DE, Baserga R. Effect of methylation on expression of microinjected genes. Proc Natl Acad Sci USA. (1982) 79:1106-10. doi: 10.1073/pnas.79.4.1106

166. Watt F, Molloy PL. Cytosine methylation prevents binding to DNA of a HeLa cell transcription factor required for optimal expression of the adenovirus major late promoter. Genes Dev. (1988) 2:1136-43. doi: 10.1101/gad.2.9.1136

167. Qi C, Xu CJ, Koppelman GH. The role of epigenetics in the development of childhood asthma. Expert Rev Clin Immunol. (2019) 15:1287302. doi: 10.1080/1744666X.2020.1686977

168. Peng C, Van Meel ER, Cardenas A, Rifas-Shiman SL, Sonawane AR, Glass $\mathrm{KR}$, et al. Epigenome-wide association study reveals methylation pathways associated with childhood allergic sensitization. Epigenetics. (2019) 14:44566. doi: 10.1080/15592294.2019.1590085
169. Arathimos R, Suderman M, Sharp GC, Burrows K, Granell R, Tilling K, et al. Epigenome-wide association study of asthma and wheeze in childhood and adolescence. Clin Epigenetics. (2017) 9:1-16. doi: 10.1186/s13148-017-0414-7

170. Reese SE, Xu CJ, Dekker HT, den Lee MK, Sikdar S, Ruiz-Arenas C. Epigenome-wide meta-analysis of DNA methylation and childhood asthma. J Allergy Clin Immunol. (2019) 143:2062-74. doi: 10.1016/j.jaci.2018.11.043

171. Cedar H, Bergman Y. Linking DNA methylation and histone modification: patterns and paradigms. Nat Rev Genet. (2009) 10:295-304. doi: 10.1038/nrg2540

172. Kidd CDA, Thompson PJ, Barrett L, Baltic S. Histone modifications and asthma: the interface of the epigenetic and genetic landscapes. Am J Respir Cell Mol Biol. (2016) 54:3-12. doi: 10.1165/rcmb.2015-0050TR

173. Harb H, Raedler D, Ballenberger N, Böck A, Kesper DA, Renz H, et al. Childhood allergic asthma is associated with increased IL-13 and FOXP3 histone acetylation. J Allergy Clin Immunol. (2015) 136:2002. doi: 10.1016/j.jaci.2015.01.027

174. Mellor J, Dudek P, Clynes D. A glimpse into the epigenetic landscape of gene regulation. Curr Opin Genet Dev. (2008) 18:116-22. doi: 10.1016/j.gde.2007.12.005

175. Wei JW, Huang K, Yang C, Kang CS. Non-coding RNAs as regulators in epigenetics (Review). Oncol Rep. (2017) 37:3-9. doi: 10.3892/or.2016.5236

176. Zaratiegui M, Irvine DV, Martienssen RA. Noncoding RNAs and gene silencing. Cell. (2007) 128:763-76. doi: 10.1016/j.cell.2007.02.016

177. Zhang G, Pradhan S. Mammalian epigenetic mechanisms. IUBMB Life. (2014) 66:240-56. doi: 10.1002/iub.1264

178. Yang IV, Lozupone CA, Schwartz DA. The environment, epigenome, and asthma. J Allergy Clin Immunol. (2017) 140:14-23. doi: 10.1016/j.jaci.2017.05.011

179. Zou YR, Sunshine MJ, Taniuchi I, Hatam F, Killeen N, Littman DR. Epigenetic silencing of CD4 in T cells committed to the cytotoxic lineage. Nat Genet. (2001) 29:332-6. doi: 10.1038/ng750

180. Zhu J, Yamane $\mathrm{H}$, Paul WE. Differentiation of effector CD4+ $\mathrm{T}$ cell populations. Annu Rev Immunol. (2010) 28:44589. doi: 10.1146/annurev-immunol-030409-101212

181. Pham TH, Benner C, Lichtinger M, Schwarzfischer L, Hu Y, Andreesen R, et al. Dynamic epigenetic enhancer signatures reveal key transcription factors associated with monocytic differentiation states. Blood. (2012) 119:16171. doi: 10.1182/blood-2012-01-402453

182. Gomez JL. Epigenetics in asthma. Curr Allergy Asthma Rep. (2019) 19:56. doi: 10.1007/s11882-019-0886-y

183. Onodera A, Kokubo K, Nakayama T. Epigenetic and transcriptional regulation in the induction, maintenance, heterogeneity, and recallresponse of effector and memory Th2 cells. Front Immunol. (2018) 9:2929. doi: 10.3389/fimmu.2018.02929

184. Barton S, Ngo S, Costello P, Garratt E, El-heis S, Clarke-harris R, et al. DNA methylation of Th2 lineage determination genes at birth is associated with allergic outcomes in childhood. Clin Exp Allergy. (2018). 47:1599608. doi: 10.1111/cea.12988

185. Brand S, Kesper DA, Teich R, Kilic-Niebergall E, Pinkenburg O, Bothur E, et al. DNA methylation of TH1/TH2 cytokine genes affects sensitization and progress of experimental asthma. J Allergy Clin Immunol. (2012) 129:160210.e6. doi: 10.1016/j.jaci.2011.12.963

186. Yang I, Liu AH, Pedersen B, O’Connor GT, Teach SJ, Kattan M, et al. DNA methylation and childhood asthma in the inner-city. J Allergy Clin Immunol. (2015) 135:AB163. doi: 10.1016/j.jaci.2014.12.1470

187. Adcock IM, Ford P, Ito K, Barnes PJ. Epigenetics and airways disease. Respir Res. (2006) 7:1-19. doi: 10.1186/1465-9921-7-21

188. Su RC, Becker AB, Kozyrskyj AL, HayGlass KT. Altered epigenetic regulation and increasing severity of bronchial hyperresponsiveness in atopic asthmatic children. J Allergy Clin Immunol. (2009) 124:11168. doi: 10.1016/j.jaci.2009.08.033

189. Malmhäll C, Alawieh S, Lu Y, Sjöstrand M, Bossios A, Eldh M, et al. MicroRNA-155 is essential for TH2-mediated allergen-induced eosinophilic inflammation in the lung. J Allergy Clin Immunol. (2014) 133:142938.e7. doi: 10.1016/j.jaci.2013.11.008

190. Perry MM, Baker JE, Gibeon DS, Adcock IM, Chung KF. Airway smooth muscle hyperproliferation is regulated by MicroRNA-221 in severe asthma. Am J Respir Cell Mol Biol. (2014) 50:7-17. doi: 10.1165/rcmb.2013-0067OC 
191. Kärner J, Wawrzyniak M, Tankov S, Runnel T, Aints A, Kisand K, et al. Increased microRNA-323-3p in IL-22/IL-17-producing T cells and asthma: a role in the regulation of the TGF- $\beta$ pathway and IL-22 production. Allergy Eur J Allergy Clin Immunol. (2017) 72:55-65. doi: 10.1111/all.12907

192. Elbehidy RM, Youssef DM, El-Shal AS, Shalaby SM, Sherbiny HS, Sherief LM, et al. MicroRNA-21 as a novel biomarker in diagnosis and response to therapy in asthmatic children. Mol Immunol. (2016) 71:10714. doi: 10.1016/j.molimm.2015.12.015

193. Karam RA, Abd Elrahman DM. Differential expression of miR155 and Let-7a in the plasma of childhood asthma: Potential biomarkers for diagnosis and severity. Clin Biochem. (2019) 68:30-6. doi: 10.1016/j.clinbiochem.2019.04.007

194. Bacchetta R, Gambineri E, Roncarolo MG. Role of regulatory T cells and FOXP3 in human diseases. J Allergy Clin Immunol. (2007) 120:22735. doi: 10.1016/j.jaci.2007.06.023

195. Hew KM, Walker AI, Kohli A, Garcia M, Syed A, Mcdonald-Hyman C, et al. Childhood exposure to ambient polycyclic aromatic hydrocarbons is linked to epigenetic modifications and impaired systemic immunity in T cells. Clin Exp Allergy. (2015) 45:238-48. doi: 10.1111/cea.12377

196. Brunst KJ, Leung YK, Ryan PH, Khurana Hershey GK, Levin L, Ji H, et al. Forkhead box protein 3 (FOXP3) hypermethylation is associated with diesel exhaust exposure and risk for childhood asthma. J Allergy Clin Immunol. (2013) 131:1-6. doi: 10.1016/j.jaci.2012.10.042

197. Chen B, Sun L, Zhang X. Integration of microbiome and epigenome to decipher the pathogenesis of autoimmune diseases. J Autoimmun. (2017) 83:31-42. doi: 10.1016/j.jaut.2017.03.009

198. Conrad ML, Ferstl R, Teich R, Brand S, Blümer N, Yildirim AÖ, et al. Maternal TLR signaling is required for prenatal asthma protection by the nonpathogenic microbe Acinetobacter lwoffii F78. J Exp Med. (2009) 206:2869-77. doi: 10.1084/jem.20090845

199. Brand S, Teich R, Dicke T, Harb H, Yildirim AÖ, Tost J, et al. Epigenetic regulation in murine offspring as a novel mechanism for transmaternal asthma protection induced by microbes. J Allergy Clin Immunol. (2011) 128:618-25.e1-7. doi: 10.1016/j.jaci.2011.04.035

200. Kyburz A, Fallegger A, Zhang X, Altobelli A, Artola-Boran M. Transmaternal Helicobacter pylori exposure reduces allergic airway inflammation in offspring through regulatory T-cells. J Autism Dev Disord. (2017) 47:54962. doi: 10.1016/j.jaci.2018.07.046

201. Straubinger K, Paul S, Prazeres Da Costa O, Ritter M, Buch T, Busch DH, et al. Maternal immune response to helminth infection during pregnancy determines offspring susceptibility to allergic airway inflammation. J Allergy Clin Immunol. (2014) 134:1271-9.e10. doi: 10.1016/j.jaci.2014.05.034

202. Smits HH, Akdis CA. In utero priming by worms protects against respiratory allergies. J Allergy Clin Immunol. (2014) 134:1280-1. doi: 10.1016/j.jaci.2014.08.051

203. Michel S, Busato F, Genuneit J, Pekkanen J, Dalphin JC, Riedler J, et al. Farm exposure and time trends in early childhood may influence DNA methylation in genes related to asthma and allergy. Allergy Eur J Allergy Clin Immunol. (2013) 68:355-64. doi: 10.1111/all.12097

204. Lund RJ, Osmala M, Malonzo M, Lukkarinen M, Leino A, Salmi J, et al. Atopic asthma after rhinovirus-induced wheezing is associated with DNA methylation change in the SMAD3 gene promoter. Allergy Eur J Allergy Clin Immunol. (2018) 73:1735-40. doi: 10.1111/all.13473

205. Paparo L, Nocerino R, Cosenza L, Aitoro R, D’Argenio V, Del Monaco V, et al. Epigenetic features of FoxP3 in children with cow's milk allergy. Clin Epigenetics. (2016) 8:4-9. doi: 10.1186/s13148-016-0252-z

206. GINA (2020). Global Initiative for Asthma. Available online at: https:// ginasthma.org (accessed Octorber 28, 2020).

207. Anwar MA, Saleh AI, Al Olabi R, Al Shehabi TS, Eid AH. Glucocorticoidinduced fetal origins of adult hypertension: association with epigenetic events. Vascul Pharmacol. (2016) 82:41-50. doi: 10.1016/j.vph.2016.02.002

208. Anan K, Hino S, Shimizu N, Sakamoto A, Nagaoka K, Takase R, et al. LSD1 mediates metabolic reprogramming by glucocorticoids during myogenic differentiation. Nucleic Acids Res. (2018) 46:544154. doi: 10.1093/nar/gky234

209. Xiao C, Biagini Myers JM, Ji H, Metz K, Martin LJ, Lindsey M, et al. Asthma corticosteroid treatment response. J Allergy Clin Immunol. (2016) 136:923-31. doi: 10.1016/j.jaci.2015.01.045
210. Pitari G, Malergue F, Martin F, Philippe JM, Massucci MT, Chabret C, et al. Pantetheinase activity of membrane-bound Vanin-1: Lack of free cysteamine in tissues of Vanin-1 deficient mice. FEBS Lett. (2000) 483:14954. doi: 10.1016/S0014-5793(00)02110-4

211. Ito K, Caramori G, Lim S, Oates T, Fan Chung K, Barnes PJ, et al. Expression and activity of histone deacetylases in human asthmatic airways. Am J Respir Crit Care Med. (2002) 166:392-6. doi: 10.1164/rccm.2110060

212. Liang L, Willis-Owen SAG, Laprise C, Wong KCC, Davies GA, Hudson TJ, et al. An epigenome-wide association study of total serum immunoglobulin e concentration. Nature. (2015) 520:670-4. doi: 10.1038/nature14125

213. Syed A, Garcia MA, Lyu S-C, Bucayu R, Kohli A, Ishida S, et al. Peanut oral immunotherapy results in increased antigen-induced $\mathrm{T}$ reg function and hypomethylation of FOXP3. J Allergy Clin Immunol. (2014) 133:50010. doi: 10.1016/j.jaci.2013.12.1037

214. Yang G, Liu ZQ, Yang PC. Treatment of allergic rhinitis with probiotics: an alternative approach. $N$ Am J Med Sci. (2013) 5:465-8. doi: 10.4103/1947-2714.117299

215. Durack J, Kimes NE, Lin DL, Rauch M, McKean M, McCauley K, et al. Delayed gut microbiota development in high-risk for asthma infants is temporarily modifiable by Lactobacillus supplementation. Nat Commun. (2018) 9:707. doi: 10.1038/s41467-018-03157-4

216. Mangiola S, Young ND, Korhonen P, Mondal A, Scheerlinck JP, Sternberg PW, et al. Getting the most out of parasitic helminth transcriptomes using HelmDB: implications for biology and biotechnology. Biotechnol Adv. (2013) 31:1109-19. doi: 10.1016/j.biotechadv.2012.12.004

217. Martin J, Rosa BA, Ozersky P, Hallsworth-Pepin K, Zhang X, BhonagiriPalsikar V, et al. Helminthnet: Expansions to Nematodenet and an introduction to Trematodenet. Nucleic Acids Res. (2015) 43:D698706. doi: 10.1093/nar/gku1128

218. Howe KL, Bolt BJ, Cain S, Chan J, Chen WJ, Davis P, et al. WormBase 2016: expanding to enable helminth genomic research. Nucleic Acids Res. (2016) 44:D774-80. doi: 10.1093/nar/gkv1217

219. Santos LN, Pacheco LGC, Silva Pinheiro C, Alcantara-Neves NM. Recombinant proteins of helminths with immunoregulatory properties and their possible therapeutic use. Acta Trop. (2017) 166:202-11. doi: 10.1016/j.actatropica.2016.11.016

220. Jefferis R. Posttranslational modifications and the immunogenicity of biotherapeutics. J Immunol Res. (2016) 2016:5358272. doi: 10.1155/2016/5358272

221. Potaczek DP, Harb H, Michel S, Alhamwe BA, Renz H, Tost J. Epigenetics and allergy: from basic mechanisms to clinical applications. Epigenomics. (2017) 9:539-71. doi: 10.2217/epi-2016-0162

222. Louwies T, Johnson AC, Orock A, Yuan T, Greenwood-Van Meerveld B. The microbiota-gut-brain axis: an emerging role for the epigenome. Exp Biol Med. (2020) 245:138-45. doi: 10.1177/1535370219891690

223. Kabesch M, Tost J. Recent findings in the genetics and epigenetics of asthma and allergy. Semin Immunopathol. (2020) 42:43-60. doi: 10.1007/s00281-019-00777-w

224. Tiffon C. The impact of nutrition and environmental epigenetics on human health and disease. Int J Mol Sci. (2018) 19:3425. doi: 10.3390/ijms19113425

225. Bae DJ, Jun JA, Chang HS, Park JS, Park CS. Epigenetic changes in asthma: role of DNA CpG methylation. Tuberc Respir Dis. (2020) 83:113. doi: $10.4046 /$ trd.2018.0088

226. Alhamwe BA, Miethe S, Pogge von Strandmann E, Potaczek DP, Garn H. Epigenetic regulation of airway epithelium immune functions in asthma. Front Immunol. (2020) 11:1747. doi: 10.3389/fimmu.2020.01747

Conflict of Interest: The authors declare that the research was conducted in the absence of any commercial or financial relationships that could be construed as a potential conflict of interest.

Copyright (c) 2021 Fiuza, Fonseca, Meirelles, Marques, da Silva and Figueiredo. This is an open-access article distributed under the terms of the Creative Commons Attribution License (CC BY). The use, distribution or reproduction in other forums is permitted, provided the original author(s) and the copyright owner(s) are credited and that the original publication in this journal is cited, in accordance with accepted academic practice. No use, distribution or reproduction is permitted which does not comply with these terms. 